\title{
Clostridium difficile infection: Early history, diagnosis and molecular strain typing methods
}

\author{
C. Rodriguez ${ }^{\text {a, * }}$, J. Van Broeck ${ }^{\text {b }}$, B. Taminiau ${ }^{\text {a }}$, M. Delmée ${ }^{\text {b }}$, G. Daube ${ }^{\text {a }}$ \\ ${ }^{a}$ Food Science Department, FARAH, Faculty of Veterinary Medicine, University of Liège, Liège, Belgium \\ belgian Reference Centre for Clostridium Difficile (NRC), Pôle de microbiologie médicale, Université Catholique de Louvain, Brussels, Belgium
}

\section{A R T I C L E I N F O}

\section{Article history:}

Received 25 February 2016

Received in revised form

18 April 2016

Accepted 2 May 2016

Available online 26 May 2016

Keywords:

C. difficile

Infection

Toxins

Laboratory diagnosis

Typing methods

\begin{abstract}
A B S T R A C T
Recognised as the leading cause of nosocomial antibiotic-associated diarrhoea, the incidence of Clostridium difficile infection (CDI) remains high despite efforts to improve prevention and reduce the spread of the bacterium in healthcare settings. In the last decade, many studies have focused on the epidemiology and rapid diagnosis of CDI. In addition, different typing methods have been developed for epidemiological studies. This review explores the history of $C$. difficile and the current scope of the infection. The variety of available laboratory tests for CDI diagnosis and strain typing methods are also examined.
\end{abstract}

(c) 2016 Elsevier Ltd. All rights reserved.

\section{Contents}

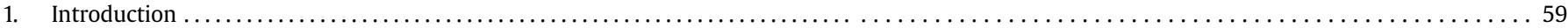

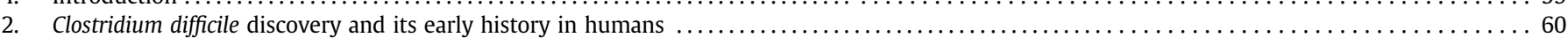

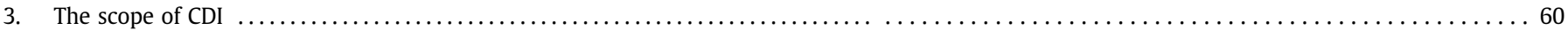

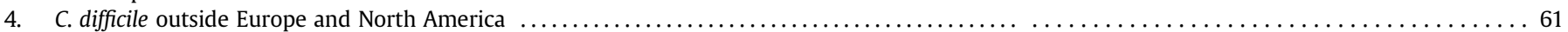

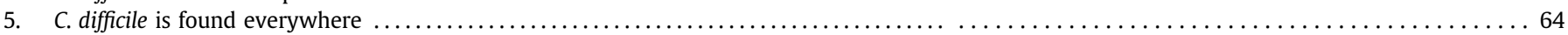

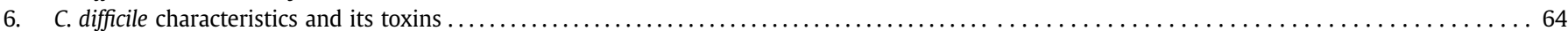

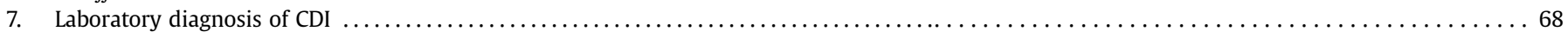

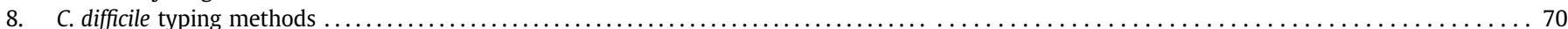

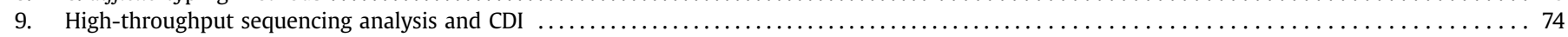

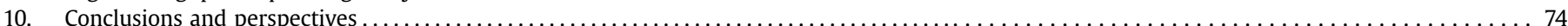

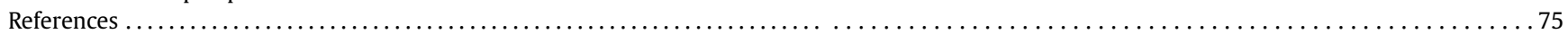

\section{Introduction}

Clostridium difficile is one of the most important nosocomial pathogens in humans. It is responsible for outbreaks of hospitalacquired infection, with symptoms including serious diarrhoea

\footnotetext{
* Corresponding author. University of Liège, Faculty of Veterinary Medicine (DDA FARAH), Quartier Vallée 2, Avenue de Cureghem, 10 (B43b), 4000 Liège, Belgium.

E-mail address: c.rodriguez@ulg.ac.be (C. Rodriguez).
}

and, in several cases, pseudomembranous colitis and even death. Although the principal risk factors in patients are a history of antibiotic treatment, an age of over 65 years, and prolonged hospitalisation $[1,2]$, in recent years, studies have described the bacterium spreading further into the community [3] and an increase in the incidence and severity of nosocomial $C$. difficile infection (CDI) in North America and Europe [4]. This rise has been attributed to the emergence of new hypervirulent strains, including PCRribotype 027 [5] and PCR-ribotype 078 [6], which has been associated with antimicrobial exposure. Furthermore, a significant 
correlation between the lack of PCR-ribotype diversity in healthcare settings and greater antimicrobial resistance has been observed [7].

In the past years, several studies and guidelines have been published to compare CDI incidence among different clinical settings, to increase the awareness of $C$. difficile and to improve the diagnosis and management of the infection [8]. This review is intended to describe the history of $C$. difficile, starting from the first descriptions up to the present, including the current knowledge regarding the detection, typing methods, and laboratory diagnosis of CDI.

\section{Clostridium difficile discovery and its early history in humans}

C. difficile was first identified by Hall and O'Toole in 1935, in a study of the daily microbial changes in the faeces of ten normal breast-fed infants up to the tenth day, when they left the hospital. The bacterium was described as a strict anaerobe with subterminal, non-bulging, elongate spores. In recognition of the difficulty of its isolation and study, it was originally named Bacillus difficilis [9]. Another remarkable property was its pathogenicity. Some strains were capable of producing toxins and caused respiratory death, with marked edema in the subcutaneous tissues of guinea pigs, rabbits, cats, dogs, rats and pigeons and convulsions in guinea pigs similar to those of tetanus. Its toxin was thermolabile, being inactivated in $5 \mathrm{~min}$ at $60^{\circ} \mathrm{C}$, but was not absorbed from the intestinal tract of the guinea pig, rat and dog: it acted only upon injection into the tissues [10]. In 1938, the bacterium B. difficilis was reclassified into the genus Clostridium [11] and C. difficile nomenclature was adopted by the Approved List of Bacterial Names [12].

Between 1940 and 1962, only two studies in the literature refer to $C$. difficile in humans $[13,14]$. However, there was no evidence in these cases that $C$. difficile was pathogenic. In the 1970s, a number of reports focused on the isolation of $C$. difficile from different hospitalised cases [15-21], but there did not seem to be an obvious pathogenic role in these cases, and $C$. difficile was still considered to be part of the normal faecal flora of humans. During this period, the first studies in animal models were published $[22,23]$. One of these studies [23] reported a cytopathic toxin in tissue-cultured cells and suggested the activation of an uncultivated virus. However, in retrospect, these findings could represent a description of the cytopathic effect of $C$. difficile induced by its toxins [24].

Pseudomembranous colitis (PMC) was first described in 1893 [25], prior to the availability of antibiotics, as a post-operative complication of gastrojejunostomy for an obstructive peptic ulcer in a young woman. Ten days after surgery, the patient developed haemorrhagic diarrhoea and died. After autopsy, the disease was identified as diphtheric colitis [26]. In subsequent years, many other early cases of PMC were recorded after surgical operations, in particular for patients with obstructive colorectal carcinoma [27] or under antimicrobial therapy [28-30]; however, while many studies showed important clues, its association with $C$. difficile would not occur until 1978 [31-36]. The finding was reported by three studies that were published in the literature almost simultaneously. In March 1978, one study [37] suggested that $C$. difficile was the causative agent of PMC. The authors found high titres of toxin in the faeces of all patients with PMC studied and hypothesised that the bacterium might be present in small quantities in the intestines of healthy adults and that under the appropriate conditions, it was able to multiply and cause postoperative diarrhoea or PMC due to its potential for toxin production. In April 1978, a second study [38] reported the isolation of $C$. difficile from the faeces of a patient with clindamycin-associated PMC and demonstrated both the presence of a faecal toxin and the toxigenicity of the isolate using a tissue- culture assay. In May 1978, a third study [39] reported that C. difficile was responsible for PMC and that previous antibiotic therapy produces susceptibility to infection, presumably as a result of a change in the bacterial flora. Finally, in late 1978, it was demonstrated that vancomycin eliminates toxin-producing $C$. difficile from the colon and is associated with rapid clinical improvement in patients with pseudomembranous colitis [40]. Fig. 1 summarises the early history of $C$. difficile in humans.

Since then, the number of reports documenting $C$. difficile infection in hospitals increased, and it became the pathogen of the 90s [41]. In the early 2000s, a rise in the incidence, severity and mortality rate of CDI was reported in Europe and North America, associated with the emergence of a new hypervirulent strain, PCRribotype 027 [5]. C. difficile is now a worldwide public health concern, as it is considered the major cause of antibiotic-associated infections in healthcare settings. Three previous reviews have addressed the recent epidemiology of CDI in hospitals, nursing homes and in the community as well as the principal outbreaks reported $[2,42,43]$.

In recent years, with the availability of next-generation sequencing technologies, it has been demonstrated that $C$. difficile is closely related to the Peptostreptococcaceae family. It has therefore been suggested that $C$. difficile should be attributed to a new Peptoclostridium genus, renaming $C$. difficile to Peptoclostridium difficile. The newly proposed genus, Peptoclostridium, are Grampositive, motile, spore-forming obligate anaerobes. All strains are mesophilic or thermophilic, grow in a neutral to alkaline $\mathrm{pH}$ and are oxidase- and catalase-negative. The $\mathrm{G}+\mathrm{C}$ content of the genomic DNA ranged from 25 to $32 \mathrm{~mol} \%$ [44].

\section{The scope of CDI}

C. difficile intestinal colonisation can be asymptomatic or produce disease. The clinical manifestations of CDI range from mild or moderate diarrhoea to fulminant pseudomembranous colitis [8]. Other symptoms described are malaise, fever, nausea, anorexia, the presence of mucus or blood in the stool, cramping, abdominal discomfort and peripheral leucocytosis. Extraintestinal manifestations (arthritis or bacteraemia) have been described but are rare. Severe disease can present colonic ileus or toxic dilatation and distension with little or no diarrhoea. The worst outcome of CDI is sepsis and death [8], which is estimated to occur in $17 \%$ of cases; however, this percentage is higher among older people [45].

Antibiotic treatment [1] and advanced age have classically been associated with $C$. difficile infection and related to an increased mortality rate $[46]$. A recent review regarding CDI cost-of-illness describes a mean cost ranging from 8911 to 30,049 USD for hospitalised patients (per patient/admission/episode/infection) in the USA [47]. In Europe, the annual economic burden is estimated to be approximately 3000 million euro [48]. However, it is necessary to note that the diagnostic strategy remains suboptimal in a large number of healthcare facilities, and a significant proportion of infections may remain undiagnosed [49].

Colonisation by non-toxigenic $C$. difficile has also been described, with a prevalence ranging between $0.4 \%$ and $6.9 \%$ [50], although this prevalence is lower than the estimated asymptomatic colonisation by toxigenic strains, which is between $7 \%$ and $51 \%$ [51,52]. Furthermore, it has been hypothesised that asymptomatic carriers can be colonised by both types of strains (toxigenic and non-toxigenic) for long periods of time without developing the disease [53]. However, these asymptomatic carriers could play an important role in transmission as a source for many unexplained cases [54]. It has been suggested that the presence of non-toxigenic C. difficile in the intestinal tract protects against CDI, although there is no clear evidence to explain how these avirulent strains reduce 


\section{EARLY HISTORY OF CLOSTRIDIUM DIFFICILE IN HUMANS}

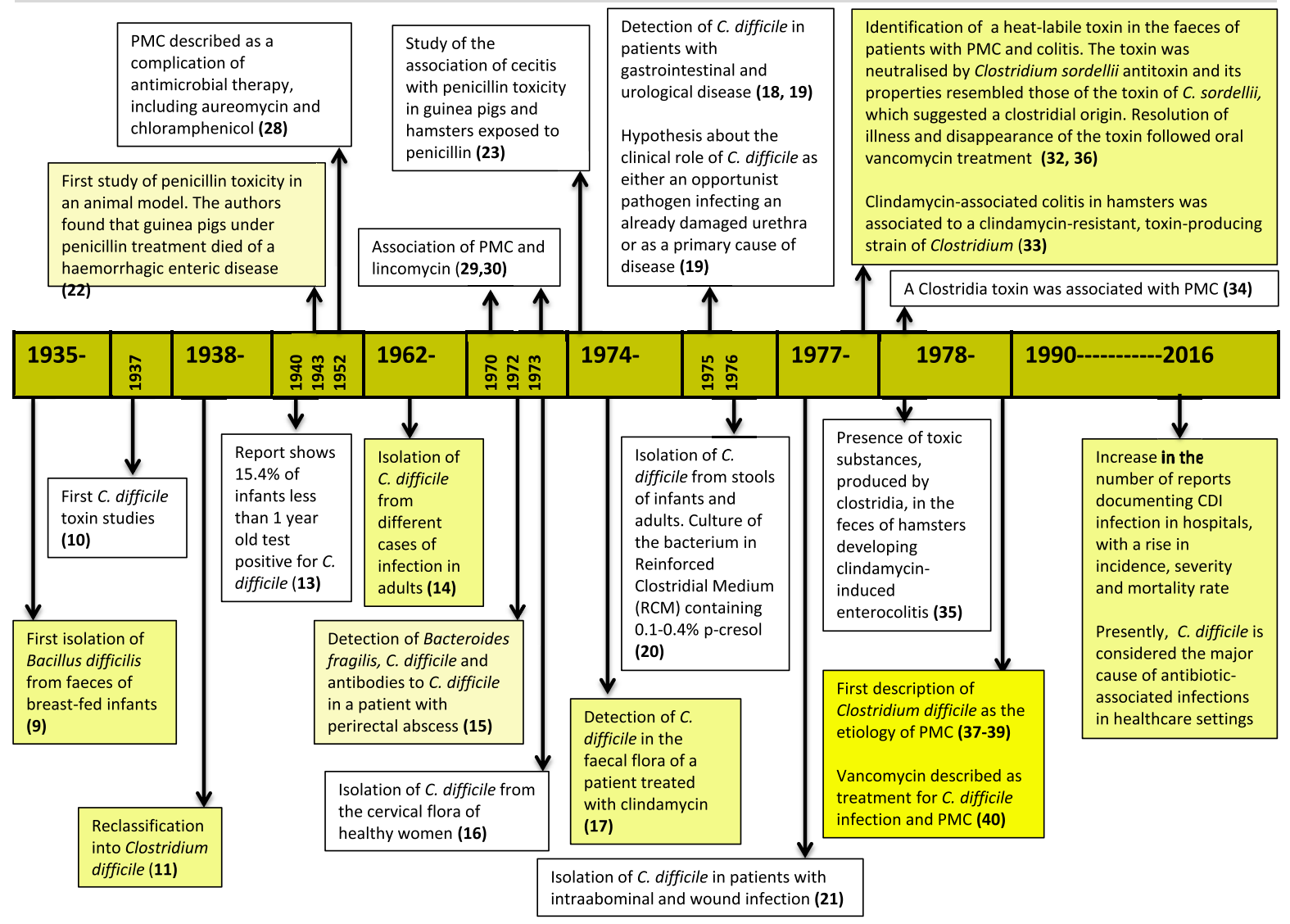

Fig. 1. Clostridium difficile history in humans PMC: pseudomembranous colitis.

the risk of developing an infection [50]. Simple competition for a niche in the gastrointestinal tract or other complex effects on mucosal immunity and nutrient acquisition have been hypothesised [50]. A variation in C. difficile non-toxigenic colonisation with age has been described, ranging from $6.9 \%$ for patients aged 60 years or more [55] to $22.8 \%$ for patients younger than 20 years of age [56], and up to 53-96\% in neonatal units [57,58], supporting the hypothesis that these strains are more prevalent in younger patients and infants [50].

\section{C. difficile outside Europe and North America}

As previously cited, $C$. difficile is the most frequent bacteria associated with nosocomial diarrhoea in Europe and North America. However, little information is available regarding the extent of the infection in other regions or developing countries. In Zimbabwe, a study conducted in a healthcare centre reported a prevalence of $8.6 \%$ in a total of 268 diarrhoeal stool samples. Further characterisation of the isolates showed that all were susceptible to metronidazole and vancomycin, but approximately $70 \%$ were resistant to co-trimoxazole, which is an antibiotic widely used in this region as prophylaxis against infections in HIV/AIDS patients [59]. In a study of the gut microbiota of 6-month-old Kenyan infants consuming home-fortified maize porridge daily for 4 months and receiving micronutrient powder containing $2.5 \mathrm{ng}$ of iron, $C$. difficile was detected with a high prevalence (56.5\%). The results obtained showed that iron fortification in infants adversely affected the gut microbiota, with an increase in the proportion of some pathogenic bacteria, including Escherichia coli, Salmonella, Clostridium perfringens and C. difficile [60]. A review [61] on the epidemiology of C. difficile in Asia shows that infection occurred at similar rates to other areas but with a predominance of variant toxin A and toxin B positive strains, including PCR-ribotypes 017 and 018. In contrast with the situation in America and Europe, PCR-ribotypes 027 and 078 have rarely been reported in Asia. The unregulated use of antibiotics in some Asian regions and the lack of surveillance raise concerns over the risk of bacterial mutation and infection [61]. An additional review describes the situation in Thailand in detail. A lack of data regarding $C$. difficile epidemiology is reported along with a high level of indiscriminate use of antimicrobials. C. difficile strains isolated from Thai patients showed a high degree of resistance for a wide range of antibiotics, including clindamycin, cefoxitin and erythromycin. Nevertheless, the strains were fully susceptible to metronidazole and vancomycin. In the same review, the authors concluded with the recommendation for a monitoring plan for $C$. difficile infections in hospital and community settings in Thailand and other Asian countries [62]. The same observation has been made for Latin America, where little data are available regarding the epidemiology of $C$. difficile in hospitals, and increased awareness and vigilance among healthcare professionals and the general public seem essential [63]. In an epidemiological study of $C$. difficile-associated diarrhoea in a Peruvian hospital, the reported overall incidence per 1000 admissions was 12.9 . As the presence of another patient with $\mathrm{CDI}$ in the same room was significantly associated with the development of diarrhoea, the authors concluded that $C$. difficile transmission commonly occurred in this healthcare setting and highlighted the need for implementing adequate hygiene programmes [64] (Table 1). 


\begin{tabular}{|c|c|c|c|c|c|c|}
\hline Continent & Country & Patients enrolled in the study/type of samples & CDI cases & Main PCR-ribotypes & Date of study $^{\mathrm{a}}$ & Reference \\
\hline \multirow[t]{3}{*}{ Africa } & Zimbabwe & $\begin{array}{l}\text { Diarrhoeal stools of outpatients over } 2 \text { years of age presenting at } \\
\text { healthcare centres }\end{array}$ & $8.6 \%(23 / 268)$ & - & 2014 & [59] \\
\hline & Kenya & $\begin{array}{l}6 \text { month-old Kenyan infants consuming home fortified maize porridge } \\
\text { and } 2.5 \mathrm{ng} \text { of iron daily for } 4 \text { months }\end{array}$ & $56.5 \%(65 / 115)^{\mathrm{b}}$ & - & 2015 & [60] \\
\hline & Nigeria & $\begin{array}{l}\text { HIV-positive inpatients of a University Teaching Hospital } \\
\text { HIV positive outpatients a University Teaching Hospital }\end{array}$ & $\begin{array}{l}43.5 \%(10 / 23) \\
14 \%(10 / 71)\end{array}$ & - & $2008-2009$ & [67] \\
\hline \multirow[t]{30}{*}{ Asia } & Japan & 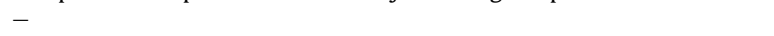 & - & 018/014/002/001 & 2013 & [61] \\
\hline & Korea & Adult patients from 17 tertiary hospitals with a diagnosis of CDI & $2.7 / 1000^{c}$ & - & $2004-2008$ & \\
\hline & Malaysia & $\begin{array}{l}\text { Stool samples from hospitalised inpatients with antibiotic associated } \\
\text { disease }\end{array}$ & $13.7 \%(24 / 175)$ & - & 2008 & \\
\hline & India & $\begin{array}{l}\text { Stool samples from hospitalised patients with antibiotic associated } \\
\text { disease }\end{array}$ & $\begin{array}{l}22.6 \% \\
(21 / 93)\end{array}$ & - & $1983-1984$ & \\
\hline & & Hospitalised patients with diarrhoea over 1 year & $11.1 \%(38 / 341)$ & - & 1991 & \\
\hline & & Diarrheal hospitalised patients & $16.7 \%(26 / 156)$ & - & 1999 & \\
\hline & & Hospitalised patients suspected of suffering CDI & $17.2 \%(17 / 99)$ & - & $2006-2008$ & \\
\hline & & Children with acute diarrhoea in hospitals & $7-11 \%$ & - & $1991 / 2001 / 2005$ & \\
\hline & & HIV seropositive adult subjects with diarrhoea & $18.08 \%$ & - & $2008-2011$ & [66] \\
\hline & Bangladesh & Children admitted to hospital with diarrhoea & $1.6 \%(13 / 814)$ & - & 1999 & [61] \\
\hline & China & Patients from a 1216 bed hospital in Shanghai & $17.1 / 10,000^{d^{2}}$ & 017/012/046 & $2007-2008$ & \\
\hline & Taiwan & Stools samples from patients with CDI at all high-risk units & $\begin{array}{l}0.45 / 1000^{\mathrm{d}} \\
7.9 / 1000^{\mathrm{e}}\end{array}$ & - & 2010 & \\
\hline & Hong-Kong & $\begin{array}{l}\text { Stools samples from patients suspected of CDI collected at a university- } \\
\text { affiliated teaching hospital }\end{array}$ & $5.1 \%(37 / 723)$ & $027^{\mathrm{f}}$ & 2008 & [137] \\
\hline & Singapore & Samples from patients of tertiary and secondary general hospitals & $\begin{array}{l}5.16 / 10,000^{\mathrm{h}} \\
2.99 / 10,000^{\mathrm{h}}\end{array}$ & - & $\begin{array}{l}2006 \\
2008\end{array}$ & [138] \\
\hline & Indonesia & Patients with diarrhoea in community and hospital settings & $1.3 \%(2 / 154)$ & - & 1997-1999 & [140] \\
\hline & Thailand & Hospitalised patients of all ages & $52.2 \%(106 / 203)$ & - & 1990 & [62] \\
\hline & & Diarrheal stools of patients between 0 and 3 years & $84.8 \%$ & & & \\
\hline & & Patients over 15 years & $10 \%(20 / 140)$ & - & 1991_1994 & \\
\hline & & Antimicrobial treated group & $1.4 \%(2 / 140)$ & & & \\
\hline & & Control group & & & & \\
\hline & & Immunocompromised patients & $4.8 \%-52.2 \%$ & - & 1998 & \\
\hline & & Febrile neutropenia paediatric oncology & $36.7 \%(11 / 30)$ & & & \\
\hline & & Human immunodeficiency virus HIV positive cohort & $58.8 \%(20 / 34)$ & & & \\
\hline & & Diarrheal patients & $36.5 \%(99 / 271)$ & & & \\
\hline & & Non diarrheal patients & $15 ; 6 \%(16 / 102)$ & & & \\
\hline & & Acquired immunodeficiency syndrome in HIV positive patients & & & & \\
\hline & & Patients of all ages & $41.7 \%(20 / 48)$ & - & 2001 & \\
\hline & & $\begin{array}{l}\text { Treated with antimicrobials } \\
\text { Non-treated with antimicrobials }\end{array}$ & $15.5 \%(13 / 84)$ & & & \\
\hline & & Hospitalised patients & $18.6 \%(107 / 574)$ & - & 2000-2001 & \\
\hline & & Hospitalised patients over 15 years & $26.9 \%(47 / 175)$ & - & 2012 & \\
\hline \multirow[t]{14}{*}{ South America } & Chile & Hospitalised patients suspected of having CDI & $20.6 \%(81 / 392)$ & $012(14.8 \%)$ & 2011-2012 & [139] \\
\hline & & & & $027(12.3 \%)$ & & \\
\hline & & & & $046(12.3 \%)$ & & \\
\hline & & & & $012 / 020(9.9 \%)$ & & \\
\hline & Argentina & Faecal specimens from hospitalised and ambulatory patients & $6.5 \%(16 / 245)$ & - & 1998-1999 & [63] \\
\hline & & Diarrheal stool samples from hospitalised patients & $36.8 \%(32 / 87)$ & - & $2000-2001$ & \\
\hline & & Hospitalised patients & $37 / 10,000^{\mathrm{d}}$ & $017(90.8 \%) / 001(5.3 \%) / 014(3.1 \%) / 031(0.7 \%)$ & 2000 & \\
\hline & & & $84 / 10,000^{\mathrm{d}}$ & & 2001 & \\
\hline & & & $67 / 10,000^{\mathrm{d}}$ & & 2002 & \\
\hline & & & $43 / 10,000^{\mathrm{d}}$ & & 2003 & \\
\hline & & & $48 / 10,000^{\mathrm{d}}$ & & 2004 & \\
\hline & & & $42 / 10,000^{\mathrm{d}}$ & & 2005 & \\
\hline & Brazil & Faeces of children over 1 year with acute diarrhoea & $5.5 \%(10 / 181)$ & - & $2000-2001$ & \\
\hline & & Faeces of children aged between 3 months and 7 years & $6.7 \%(14 / 210)$ & - & 2003 & \\
\hline
\end{tabular}


Adult hospitalised patients

Hospitalised patients suspected of having CDI

Patients of a medical surgical intensive care unit presenting nosocomial

diarrhoea

Immunosuppressed adult patients receiving antimicrobial treatment

$28.5 \%(6 / 21)$

$\begin{array}{lll}3.3 / 1000^{\mathrm{d}, \mathrm{j}} & - & 2002-2003 \\ 19.7 \%(43 / 218)^{\mathrm{k}} & 038 / 135 & 2006-2009\end{array}$

before an episode of nosocomial diarrhoea

Chile

Hospitalised patients at a university tertiary hospital suspected of

$21.7 \%(19 / 70)$

$010 / 020 / 133 / 233$

2008-2009

having $\mathrm{CD}$

Hospitalised patients suspected of having CDI

$28.2 \%(26 / 92)$

$-$

2001

$0.53 / 100$

$15.9 \%(112 / 706)$

Inpatients of a health unit

Costa Rica Patients presenting diarrhoea and receiving antimicrobial drugs

Patients with CDI in a Costa Rica hospital

Jamaica Patients with and without immunosuppressive treatment and patients

under radiotherapy

Mexico Hospitalised patients at a tertiary hospital

Puerto Rico Hospitalised patients with diarrhoea

Hospitalised patients at a tertiary hospital

$30 \%(31 / 104)$

14.1\%(16/113)

$-$

027 (54\%)

2000-2001

2003-2008

2008

2010

2009

2003-2007

$$
\text { Peru }
$$

a Study period if available or date of publication.
b Detection by 165 pyrosequencing and targeted real-time PCR.

c Detection by $16 \mathrm{~S}$ pyrosequencing and
c Incidence of CDI for adult admission.

c Incidence of CDI for adult admissior
d Incidence of CDI for admission.

e Incidence of CDI in medical care units.

f Only one strain identified as PCR-ribotype 027.

h Incidence of CDI cases per 100,000 inpatient-days.

i C. difficile was isolated from $4 / 6$ of the patients with CDI.

${ }^{j}$ C. difficile was isolated from 16/138 stool samples of patients with CDI.

${ }^{k}$ Mean incidence of CDI 1.8/1000 patient days. Highest incidence between December 2007 and August 2008 (5.5/1000 patient days).

${ }^{1}$ Global incidence of CDI per year in the hospital.

$\mathrm{m}$ Incidence in the nephrology unit. 
One of the most serious human health problems in developing regions is the microbial contamination of drinking water and foods, leading to severe gastrointestinal diseases that are exacerbated by under-nutrition and the lack of medical treatment in these regions. Water-, sanitation- and hygiene-related deaths occur almost exclusively in developing countries (99.8\%), of which $90 \%$ are the deaths of children [65]. Indeed, children are the most at-risk group, especially in the first year of life. $C$. difficile was identified among a large number of bacteria associated with diarrhoea in this population. However, the source of contamination (water, food or environment) by the enteropathogens identified in diarrheic children was not elucidated [65].

Another issue of concern is CDI in immuno-compromised patients in developing countries. In a study conducted to assess the microbial aetiologies of diarrhoea in adults infected with human immunodeficiency virus (HIV) in India, C. difficile was the most common bacterial pathogen identified, with a reported prevalence of $18 \%$ [66]. Consistent with this study, HIV-positive inpatients and outpatients in Nigeria were shown to be C. difficile-positive in $43 \%$ and $14 \%$ of cases, respectively [67] (Table 1). Both studies show the importance of establishing controlled and regulated access to antibiotics in developing countries, as well as the importance of the early diagnosis of intestinal pathogens to reduce morbidity and mortality rates, especially among HIV-positive people. In a further study evaluating CDI in travellers, infection was reported to be more commonly acquired in low- and middle-income countries. Furthermore, CDI was often acquired in the community by young patients and associated with the empirical use of antimicrobials, frequently fluoroquinolones [68].

\section{C. difficile is found everywhere}

C. difficile is ubiquitous in the environment, and the bacterium has the capacity to persist on inanimate surfaces for as long as several months [69]. These contaminated areas can contribute towards $C$. difficile transmission in healthcare settings. Bed frames, floors or bedside tables have been described as the most commonly contaminated areas in rooms used to isolate patients with C. difficile diarrhoea [70], even after detergent-based cleaning [71]. Table 2 summarises the available studies in the literature regarding the dissemination of $C$. difficile spores in healthcare settings and related environments. However, the difference in prevalence among studies may be due to the sampling and culture methods used [70] and in the cleaning programmes used to control the spread of $C$. difficile. In this context, a previous study reported that unbuffered hypochlorite ( $500 \mathrm{ppm}$ ) was less effective than phosphate buffered hypochlorite $(1600 \mathrm{ppm})$ for surface decontamination [72]. In addition to the patient room environment, the bacterium was isolated from the hands and stools of asymptomatic hospital staff and from the home of a patient suffering CDI. Furthermore, C. difficile inoculated onto a surface (floor) has been shown to persist there for five months [73]. In an intensive care unit, an outbreak of pseudomembranous colitis was attributed to the cross-contamination of inanimate environmental sources with persistence in the hospital for several weeks [77]. Regarding the medical equipment, two previous studies have reported that the replacement of electronic thermometers with single-use disposables significantly reduced the incidence of $C$. difficile-associated diarrhoea in both acute care and skilled nursing care facilities [78,79]. However, it has also been reported that with the use of disposable or electronic thermometers, there was no effect on either the overall rate of nosocomial diarrhoea or the rate of nosocomial infections [79]. A further study also describes how the use of tympanic thermometers reduces the risk of acquiring vancomycin-resistant Enterococcus and CDI by $60 \%$ and $40 \%$, respectively [80].
Increased interest in the transmission of $C$. difficile has led to new studies in the literature reporting the presence of spores in other areas never studied before. Medical staff has increasingly used mobile technology devices in hospitals, such as iPads, to access electronic patient information. A recent study [82] evaluated the contamination of 20 iPads by $C$. difficile spores in a healthcare setting. Although with the number of samples tested, there was not sufficient data to estimate the prevalence, and in addition, there was no $C$. difficile recovery, the study also reported the effect of different agents on iPad disinfection. The results showed that bleach wipes were able to remove the inoculated spores completely from the screen surface, while a microfibre cloth was more effective than alcohol wipes. As there are no existing medical guidelines specific to electronic devices, and the manufacturer recommends avoiding the use of chemicals or abrasives to clean the device, the authors emphasised the importance of reducing the tablets' environmental contact in rooms housing patients suffering from CDI.

There are few studies describing the presence of $C$. difficile in the natural environment and in the environment in the community (Table 3). The prevalence of $C$. difficile was recently studied in retail baskets, trolleys, conveyor belts and plastic bags in 17 different supermarkets from 2 cities in Saudi Arabia. The study reported a $C$. difficile prevalence of $0.75 \%$ on sampled surfaces, with the highest level of contamination in baskets and trolleys, which could suggest the need for the implementation of planned disinfection in supermarkets to control community-acquired CDI [83]. In the natural environment, the bacterium was detected in seawater, zooplankton [84], tropical soils [85] and rivers [86]. In the rural environment, $C$. difficile was recovered from homestead soils, household-stored water [87] and soils of stud farms with mature horses [88]. In this last study, $C$. difficile was inoculated in equine faeces and the bacterium was found to survive at least 4 years (no later time points were tested) when kept at room temperature and outdoors at an ambient temperature over the year.

While $C$. difficile is also known as an enteric pathogen in some food-producing and companion animal species, there are several reports describing the presence of the bacterium in the intestinal contents of apparently healthy animals (Table 3). Moreover, recently published data suggests that animals are an important source of human CDI that can spread disease through environmental contamination, direct or indirect contact, or food contamination, including carcass and meat contamination at slaughter or, in the case of crops, through the use of organic animal manure [129]. Table 3 summarises the prevalence of $C$. difficile reported in pets (dogs and cats), food animals (pigs and cattle), horses and wild animals. Despite the large number of studies describing the presence of human epidemic PCR-ribotypes in these animals, C. difficile has not been confirmed as a zoonotic agent, but it seems evident that there is a potential risk of transmission, especially in people with close contact with contaminated animals and their environment.

\section{C. difficile characteristics and its toxins}

Since its discovery in 1935, the characteristics of C. difficile growth, sporulation and virulence have been documented in detail. The fundamental aspects of the bacterium are summarised in Table 4. One of these characteristics is that $C$. difficile has no protease, phospholipase $C$ or lipase, but it is among the few bacteria able to ferment tyrosine to $p$-cresol, which is a phenolic compound that inhibits the growth of other anaerobic bacteria [134,20]. Dawson et al. (2008) [134] found that Clostridium sordellii tolerated $p$-cresol but did not produce it. Therefore, the authors suggested that the mechanism of tolerance might not be linked to the production of this organic compound. Furthermore, the increased 
Table 2

C. difficile spores in the environment of healthcare settings.

\begin{tabular}{|c|c|c|c|c|}
\hline Environment & $\begin{array}{l}\text { Positive surfaces (number or percentage of } \\
\text { positive surfaces/patient rooms) }\end{array}$ & Study conditions & $\begin{array}{l}\text { Main PCR-ribotypes (\% } \\
\text { of toxigenic strains) }\end{array}$ & Reference \\
\hline $\begin{array}{l}\text { Hospital rooms previously } \\
\text { accommodating CDI patients }\end{array}$ & $\begin{array}{l}\text { Patient-helper trapeze (5) } \\
\text { Call button (3) } \\
\text { Bed table (4) } \\
\text { Bedrail (6) } \\
\text { Tap (3) } \\
\text { Toilet (7) } \\
\text { Inner door handle (1) } \\
\text { Shackle of hand disinfectant (1) } \\
\text { Door handle facing to outer sluice (1) } \\
\text { Stethoscope (1) } \\
\text { Rail at foot-end (2) } \\
\text { Patient-helper trapeze (1) } \\
\text { Bedrail (2) } \\
\text { Toilet (3) }\end{array}$ & $\begin{array}{l}\text { Surface sampling after being } \\
\text { cleaned }\end{array}$ & $\begin{array}{l}\text { PCR-ribotype } 012 \\
\text { PCR-ribotype 020C } \\
\text { PCR-ribotype SE121 } \\
\text { PCR-ribotype } 023\end{array}$ & [70] \\
\hline $\begin{array}{l}\text { Hospital side rooms used for } \\
\text { the isolation of patients with } \\
\text { symptomatic CDI }\end{array}$ & $\begin{array}{l}\text { Floor }(45 \%) \\
\text { Light }(35 \%) \\
\text { Bed }(9 \%) \\
\text { Sink/table }(8 \%) \\
\text { Window }(3 \%)\end{array}$ & $\begin{array}{l}\text { Surface sampling after } \\
\text { detergent-based cleaning }\end{array}$ & $\begin{array}{l}\text { PCR-ribotype } 1 \\
\text { (93\% of toxigenic } \\
\text { strains) }\end{array}$ & [71] \\
\hline $\begin{array}{l}\text { Hospital with an outbreak of } \\
\text { antibiotic-associated colitis }\end{array}$ & $\begin{array}{l}\text { Environmental cultures obtained on the ward } \\
(31.4 \%) \\
\text { Environmental cultures obtained on the ward } \\
(21 \%)\end{array}$ & $\begin{array}{l}\text { Surface sampling before ward } \\
\text { disinfection } \\
\text { Surface sampling after ward } \\
\text { disinfection with unbuffered } \\
\text { hypochlorite }^{a}\end{array}$ & - & [72] \\
\hline $\begin{array}{l}\text { Environment and contacts of } \\
\text { hospitalised patients } \\
\text { carrying } C \text {. difficile in their } \\
\text { stools }\end{array}$ & $\begin{array}{l}\text { Floors and other surfaces }(9.3 \%) \\
\text { Floors }(2.6 \%)\end{array}$ & $\begin{array}{l}\text { Areas where carriers had } \\
\text { diarrhoea } \\
\text { Areas without } C \text {. difficile carriers }\end{array}$ & $\begin{array}{l}\text { ( } 100 \% \text { of toxigenic } \\
\text { strains) }\end{array}$ & [73] \\
\hline $\begin{array}{l}\text { Different areas of hospitals with } \\
\text { and without positive } \\
\text { patients for } C \text {. difficile }\end{array}$ & $\begin{array}{l}\text { Environmental cultures ( } 32.5 \%) \\
\text { Environmental cultures (1.3\%) } \\
\text { Highest counts of } C \text {. difficile from toilet seats, } \\
\text { toilet bowl rims, bathroom handrails and } \\
\text { bathroom floors } \\
\text { Highest counts of } C \text {. difficile from bed handrails } \\
\text { and near the beds }\end{array}$ & $\begin{array}{l}\text { Case-related environments } \\
\text { Control sites } \\
\text { Ambulatory patients } \\
\text { Non ambulatory patients }\end{array}$ & - & [74] \\
\hline Two elderly medicine wards & Environmental cultures (35\%) & $\begin{array}{l}\text { Two different types of cleaning } \\
\text { which included hypochlorite or } \\
\text { neutral liquid detergent }^{\mathrm{d}}\end{array}$ & - & [75] \\
\hline $\begin{array}{l}\text { Samples of the inanimate ward } \\
\text { environment on two elderly } \\
\text { medicine hospital wards (A } \\
\text { and B) }\end{array}$ & $\begin{array}{l}\text { Environmental cultures ( } 34 \% \text { ). Highest counts of } \\
\text { C. difficile (sorted in descending order) from: } \\
\text { sluice floor, commodes, toilet floors, ward } \\
\text { floors, radiators and air vents } \\
\text { Environmental cultures ( } 36 \% \text { ). Highest counts of } \\
\text { C. difficile (sorted in descending order) from: } \\
\text { commodes, toilet floors, ward floors/air vents/ } \\
\text { sluice floor and radiators }\end{array}$ & $\begin{array}{l}\text { Environmental samples for } \\
\text { ward A } \\
\text { Environmental samples for } \\
\text { ward A }\end{array}$ & - & [76] \\
\hline $\begin{array}{l}\text { Samples from surfaces of a } \\
\text { variety of areas in a nursing } \\
\text { home }\end{array}$ & $\begin{array}{l}\text { Environmental cultures (kitchen, kitchen-staff } \\
\text { locker room and bathroom, resident's rooms, } \\
\text { private bathrooms, residence hall, lifts and } \\
\text { staircase railings }(0 \%)\end{array}$ & $\begin{array}{l}\text { Sampling before and after } \\
\text { cleaning routine }\end{array}$ & - & [81] \\
\hline
\end{tabular}

production and $p$-cresol tolerance of some strains, including PCRribotype 027 strains, has led to hypotheses regarding its contribution towards $C$. difficile hypervirulence [134].

C. difficile is able to produce two major toxins, toxin A (308 kDa) and toxin $B(270 \mathrm{kDa})$, as well as the binary cytolethal distending toxin (CDT). Toxins A and B belong to the group of Large Clostridial Toxins (LCT). Only strains that produce at least one of the three toxins cause disease. Toxin $\mathrm{A}$ is considered to be an enterotoxin because it causes fluid accumulation in the bowel. Toxin B does not cause fluid accumulation but is extremely cytopathic for tissuecultured cells [130]. These toxins are encoded by two genes, $\operatorname{tcd} A$ and $t c d B$, mapping to a $19.6 \mathrm{~kb}$ pathogenicity locus (PaLoc) and containing 3 additional regulatory genes, $t c d C$, $t c d R$, and $t c d E$, that are responsible for the synthesis and regulation of toxins $A$ and $B$
[135]. Deletions, insertions, or polymorphic restriction sites in one or more of the PaLoc genes can result in toxin variant strains that produce either toxin A or toxin B [135]. While the power of purified toxin $A$ to produce pathology in vitro has been widely described, a study [136] reported that toxin B, but not toxin A, was essential for virulence. Finally, in 2011, it was shown that both mutant variants, toxin $\mathrm{A}+$ toxin $\mathrm{B}-$ and toxin $\mathrm{A}-$ toxin $\mathrm{B}+$, can cause disease [137]. It is worth noting that toxin $\mathrm{A}+\mathrm{B}-$ isolates of $C$. difficile have not been described in nature. Toxin $\mathrm{A}$ - toxin $\mathrm{B}+$ strains have been widely reported in human cases [138] but also in animals suffering from diarrhoea [139]. A previous study reported that toxin A- toxin $B+$ strains caused the same spectrum of disease that is associated with toxin $\mathrm{A}+$ toxin $\mathrm{B}+$ strains, ranging from asymptomatic colonisation to fulminant colitis, with outbreaks in hospitals and other 


\begin{tabular}{|c|c|c|c|c|}
\hline Environment/animals & Prevalence (\%) & Samples & Main PCR-ribotypes & Reference \\
\hline 17 supermarkets from two cities in Saudi Arabia & $20 / 1600(0.75 \%)$ & $\begin{array}{l}\text { Retail baskets and trolleys }(4 / 400) \\
\text { Conveyor belts }(1 / 400) \\
\text { Plastic bags }(3 / 400)\end{array}$ & $\begin{array}{l}\text { PCR-ribotype } 027 \\
4 \text { different PCR-ribotypes (with NIN) }\end{array}$ & [83] \\
\hline $\begin{array}{l}\text { Five sampling stations along the coastline of the Gulf of } \\
\text { Naples }\end{array}$ & $9 / 21(42.9 \%)$ & $\begin{array}{l}\text { Sea water }(2 / 5) \\
\text { Sediment }(0 / 5) \\
\text { Zooplankton }(3 / 5) \\
\text { Shellfish }(4 / 6)\end{array}$ & $\begin{array}{l}\text { PCR-ribotype } 003 \\
\text { PCR-ribotype } 005 \\
\text { PCR-ribotype } 009 \\
\text { PCR-ribotype } 010 \\
\text { PCR-ribotype } 056 \\
\text { PCR-ribotype } 060\end{array}$ & [84] \\
\hline $\begin{array}{l}\text { Samples from grassland, non-agricultural soils from five } \\
\text { different regions of Costa Rica }\end{array}$ & $3 / 117(3 \%)$ & Central Plateau/Dry Pacific/North & - & [85] \\
\hline Water samples $(\mathrm{n}=69)$ from 25 different rivers in Slovenia & $\begin{array}{l}42 / 69(60.9 \%) \\
17 / 25(68 \%)\end{array}$ & $\begin{array}{l}\text { Water samples } \\
\text { Rivers }\end{array}$ & $\begin{array}{l}34 \text { different PCR-ribotypes } \\
\text { PCR-ribotype } 014 \text { predominant (16.2\% } \\
\text { of all isolates) }\end{array}$ & [86] \\
\hline Samples from a rural community in Zimbabwe & $\begin{array}{l}54 / 146(37 \%) \\
14 / 234(6 \%) \\
20 / 115(17.4 \%) \\
7 / 161(4.3 \%)\end{array}$ & $\begin{array}{l}\text { Soil samples } \\
\text { Water samples } \\
\text { Chicken faces samples } \\
\text { Faecal samples of other animals }\end{array}$ & - & [87] \\
\hline \multirow[t]{7}{*}{$\begin{array}{l}\text { Samples from studfarms and farms with horses and samples } \\
\text { from faecal samples of horses }\end{array}$} & $\begin{array}{l}14 / 132(11 \%) \\
2 / 220(1 \%)\end{array}$ & $\begin{array}{l}\text { Outdoor soil samples } \\
\text { Soil samples from farms with mature horses }\end{array}$ & - & [87] \\
\hline & $\begin{array}{l}4 / 72(6 \%) \\
18 / 43(42 \%)\end{array}$ & $\begin{array}{l}\text { Diarrhoeic mature horses } \\
\text { Faecal samples of horses with colitis }\end{array}$ & - & [88] \\
\hline & $(5 \%-63 \%)$ & Foals and adults horses with gastrointestinal disease & - & [111] \\
\hline & $5 / 134(3.7 \%)$ & Faecal samples of horses at hospital admission & $\begin{array}{l}\text { PCR-ribotype } 014 \\
4 \text { additional PCR-ribotypes with NIN }\end{array}$ & [112] \\
\hline & 10/73 (13.7\%) & Faecal samples of hospitalised horses & $\begin{array}{l}\text { PCR-ribotype } 014 \\
6 \text { additional PCR-ribotypes with NIN }\end{array}$ & [113] \\
\hline & $4 / 82(4.8 \%)$ & Faecal samples of horses at hospital admission & 17 different PCR-ribotypes & [114] \\
\hline & $14 / 62(23 \%)$ & Faecal samples from diarrheic horses & 6 different PCR-ribotypes & [115] \\
\hline \multirow[t]{13}{*}{ Wild animals } & $\begin{array}{l}2 \text { fatal cases of elephants } \\
\text { with enterocolitis }\end{array}$ & Samples of intestinal contents of two Asian Elephants & PCR-ribotype I & [89] \\
\hline & $\begin{array}{l}1 \text { clinical case of an ocelot } \\
\text { with diarrhoea }\end{array}$ & Stool sample of a male Ocelot & - & [90] \\
\hline & $11 / 30(36.7 \%)$ & Pooled faecal samples of captive white-tailed deer & PCR-ribotype 078 & [91] \\
\hline & $2 / 34(5.9 \%)$ & Non-diarrheic maned wolf and a diarrheic ocelot & - & [92] \\
\hline & $7 / 175(4 \%)$ & Droppings from barn Swallows & $\begin{array}{l}\text { PCR-ribotype SB3, } \\
\text { PCR-ribotype SB159 } \\
\text { PCR-ribotype S166 }\end{array}$ & [93] \\
\hline & $0 / 46550 \%)$ & Cloacal samples of migrating passerine birds & - & [94] \\
\hline & $7 / 200(3.5 \%)$ & $\begin{array}{l}\text { Faecal samples from zoo animals (chimpanzee, dwarf goat, } \\
\text { Iberian ibex and plains zebra) }\end{array}$ & $\begin{array}{l}\text { PCR-ribotype } 078 \\
\text { PCR-ribotype } 039 \\
\text { PCR-ribotype } 110\end{array}$ & [95] \\
\hline & $\begin{array}{l}15 \text { cases of enterocolitis in } \\
\text { harbor seals }\end{array}$ & Faecal samples of juvenile harbor seals (Phoca vitulina) & - & [96] \\
\hline & $3 / 46(6.5 \%)$ & Stool samples from free-living South America coati & $\begin{array}{l}\text { PCR-ribotype 014/020 } \\
\text { PCR-ribotype } 106 \\
\text { PCR-ribotype } 013\end{array}$ & [97] \\
\hline & 5/109 (4.6\%) & Faecal samples of free-living South America coatis & - & [98] \\
\hline & $95 / 724(13.1 \%)$ & Faecal samples of black and Noway rats & 35 different PCR-ribotypes & [99] \\
\hline & $7 / 161$ (4.4\%) & Faecal samples of feral swine & - & [100] \\
\hline & $41 / 60(25 \%)$ & Faecal samples of Iberian pigs (free range system) & PCR-ribotype 078 & [101] \\
\hline \multirow[t]{3}{*}{ Pets (dogs and cats) } & $14 / 139(10 \%)$ & Faecal samples of dogs & $\begin{array}{l}\text { PCR-ribotype } 001 \\
3 \text { other PCR-ribotypes (with NIN) }\end{array}$ & [102] \\
\hline & $62 / 204(30 \%)$ & Faecal samples of dogs & 29 PCR-ribotypes & [103] \\
\hline & $16 / 117(13.6 \%)$ & Faecal samples of dogs & & [104] \\
\hline
\end{tabular}


$(33.3 \%-100 \%)$

Faecal samples from 18 puppies aged between 7 and 55 days

CR-ribotype 010

PCR-ribotype 078

PCR-ribotype 213

PCR-ribotype 009

PCR-ribotype 020

PCR-ribotype 009

PCR-ribotype 009

PCR-ribotype 010

PCR-ribotype 014

PCR-ribotype 010

PCR-ribotype 014/020

PCR-ribotype 039

PCR-ribotype 045
PCR-ribotype with NIN

\section{Faecal samples of two adult cats}

diarrhoea

$23 / 245(9.4 \%)$

Pigs (piglets and adult pigs at slaughter

$1 / 100(1 \%)$

$45 / 67(67.1 \%)$

$2 / 61(3.3)$

$58 / 677(8.6 \%)$

$0 / 165(0 \%)$

$241 / 513(47 \%)$

$30 / 436(6.9 \%)$

$103 / 174(59.2 \%)$

$11 / 11(100 \%)$

Cattle (calves and adult cattle)

Faecal samples of cats in a veterinary hospital

Faecal samples from pigs at slaughter (5-6 months)

Faecal samples from neonatal piglets

Faecal samples from pigs at slaughter

Faecal samples from pigs at slaughter

Faecal samples from pigs at slaughter

Facal samples fir

Faecal samples from neonatal piglets

Faecal samples from neonatal diarrhoeic piglets

Faecal samples from neonatal diarrhoeic piglets
Faecal samples from neonatal non diarrhoeic piglets

Faecal samples from neonatal non diarrhoeic piglets
Faecal samples of finishing pigs at farm (13-27 weeks)

Faecal samples of calves ( $<12$ weeks)

Faecal samples of cattle at slaughter (15-56 months)

10/101 (9.9\%)

$3 / 67(4.5 \%)$

$176 / 999(17.6 \%)$

Faecal samples of cattle at slaughter

Faecal samples of calves

$90 / 150(60 \%)$

Faecal samples of calves aged between 3 and 25 days

Faecal samples of dairy and beef cow 
Table 4

Fundamental aspects of the bacterium.

\begin{tabular}{|c|c|c|c|}
\hline C. difficile characteristics & & Data & Reference \\
\hline \multirow[t]{6}{*}{ Cells } & Gram & Gram-positive & [130] \\
\hline & Motility & Motile in broth cultures & \\
\hline & Ciliature & Peritrichous & \\
\hline & Size & $0.5-1.9 \mu \mathrm{m}$ wide & \\
\hline & & $3.0-1.9 \mu \mathrm{m}$ long & \\
\hline & Chains & Some strains produce chains of $2-6$ cells aligned end-to-end & \\
\hline \multirow[t]{3}{*}{ Spores } & Shape and position & Oval, subterminal (rarely terminal) and swell the cell & \\
\hline & Cogerminants for spores & Bile salts (cholate, taurocholate) & [131] \\
\hline & & Glycine, histidine & \\
\hline \multirow[t]{5}{*}{ Colonies } & Morphology & Circular, occasionally rhizoid & {$[10,130]$} \\
\hline & Size & $2-5 \mathrm{~mm}$ & \\
\hline & Colour & Opaque, greyish, whitish, with a matt-to-glossy surface ${ }^{a}$ & [133] \\
\hline & & Yellow fluorescence ${ }^{\mathrm{b}}$ & \\
\hline & Other characteristics & $\begin{array}{l}\text { Non-haemolytic. They produce a characteristic odour, described as smelling like cow manure, } \\
\text { a barnyard or horse stables }\end{array}$ & {$[132]$} \\
\hline \multirow[t]{2}{*}{ Growth temperature } & Optimum & $30-37^{\circ} \mathrm{C}$ & {$[10,130]$} \\
\hline & Range of growth & $25-45^{\circ} \mathrm{C}$ & \\
\hline $\mathrm{pH}$ & & 5 (minimum) & \\
\hline Water activity & & 0.969 (minimum) & \\
\hline Atmosphere & & Anaerobic conditions & \\
\hline \multirow{3}{*}{$\begin{array}{c}\text { Cultures in PYG after } 5 \\
\text { days of incubation }{ }^{c}\end{array}$} & $\mathrm{pH}$ & $5.0-5.5$ & {$[130]$} \\
\hline & Products in this medium & Acetic, isobutyric, butyric, isovaleric, valeric, isocaproic, formic and lactic acids ${ }^{\mathrm{d}}$ & \\
\hline & Other characteristics & Cultures are turbid with smooth sediments & \\
\hline
\end{tabular}

healthcare settings worldwide [135]. It must be noted that toxin Atoxin $\mathrm{B}+$ strains are sometimes reported solely on the basis of the lack of $t c d A$ amplification; however, there are some $\mathrm{A}+$ variant strains with a partially deleted $t c d A$ fragment [140].

Both toxins A and B translocate to the cytosol of target cells and inactivate small GTP-binding proteins. By glycosylating small GTPases, the two toxins cause actin condensation and cell rounding, which is followed by cell death. Toxin A acts primarily within the intestinal epithelium, while toxin B has broader cell tropism [141]. Both toxins induce the production of tumour necrosis factor alpha and pro-inflammatory interleukins, which induce the inflammatory cascade and the pseudomembrane formation in the colon. The endoscopy of $C$. difficile colitis shows a colonic mucosa with multiple whitish plaques, usually raised and adherent, of a size varying from a few millimetres to $1-2 \mathrm{~cm}$; the cells can even be confluent in severe disease. The intervening colonic mucosa can be oedematous, granular, hyperaemic or completely normal [142].

The genes $c d t A$ and $c d t B$, encoding the CDT, which belongs to the group of clostridial binary toxins, are not found on the PaLoc. This toxin is encoded on a separate region of the chromosome (CdtLoc). It has been described that all strains with $c d t A$ and $c d t B$ genes are variant strains (with changes in the $t c d A$ and $t c d B$ genes) [143]. In contrast, most types not producing binary toxin have toxin genes very similar to the reference strain, VPI 10463. ${ }^{1}$ These CDT + strains represent up to $6 \%$ of the toxigenic isolates from hospitalised patients [143]. The production of CDT is frequently associated with hypervirulent strains. CDT has been described as causing the collapse of the actin cytoskeleton and cell death. The lipolysisstimulated lipoprotein receptor (LSR) is known to be the host receptor for the C. difficile CDT toxin [144]. Furthermore, the CDT toxin also induces the formation of microtubule-based protrusions and increases the adherence of the bacterium [145]. While CDT is still being investigated, some studies have already reported data regarding the clinical relevance of this toxin. Bacci et al. (2011) [146]

\footnotetext{
1 http://www.mf.uni-mb.si/mikro/tox/.
}

associated the presence of CDT in patients with higher case-facility (death) rates. Other authors also found that CDT was a marker for more virulent $C$. difficile strains or that it contributed directly to strain virulence. Tagashira et al. (2013) [147] described two cases of fulminant colitis due to CDT + strains in the same ward of a hospital in Japan occurring within ten weeks of each other. A further study suggested that CDT was a predictor of recurrent infection, and its presence may require longer antibiotic treatments [148]. CDT $+C$. difficile strains that do not produce toxins $A$ and $B$ have been described in independent cases of patients with diarrhoea suspected of having CDI [149].

\section{Laboratory diagnosis of CDI}

To aid in the surveillance of CDI and to increase comparability between clinical settings, standardised case definitions have been proposed (Fig. 2) [8]. A laboratory diagnosis of CDI must be based on the detection of $C$. difficile toxins or on the isolation of toxigenic C. difficile strains from stool samples [150]. However, these results should be combined with the clinical findings to diagnose the disease. The clinical manifestation includes diarrhoea with the passage of 3 or more unformed stools in 24 or fewer consecutive hours [8]. In this context, only unformed and fresh stools should be tested for diagnostic purposes (the specimen should be loose enough to take the shape of the container). The cytotoxic activity is lost very quickly, meaning if the analysis of fresh specimens is not possible, the samples should be stored at $4{ }^{\circ} \mathrm{C}$ or below. However, cultures are not affected by temporal conditions due to sporulation [150]. Formed stools only must be tested if they come from patients with ileus or potential toxic megacolon or in the case of epidemiological studies [150].

A recent guide to the utilisation of the microbiology laboratory for the diagnosis of infectious diseases [151] highlights the importance of the collection device, temperature and transport time because the interpretation of the results will depend on the quality of the specimens received for analysis. Specifically, regarding $C$. difficile, the recommendations are that the stool 

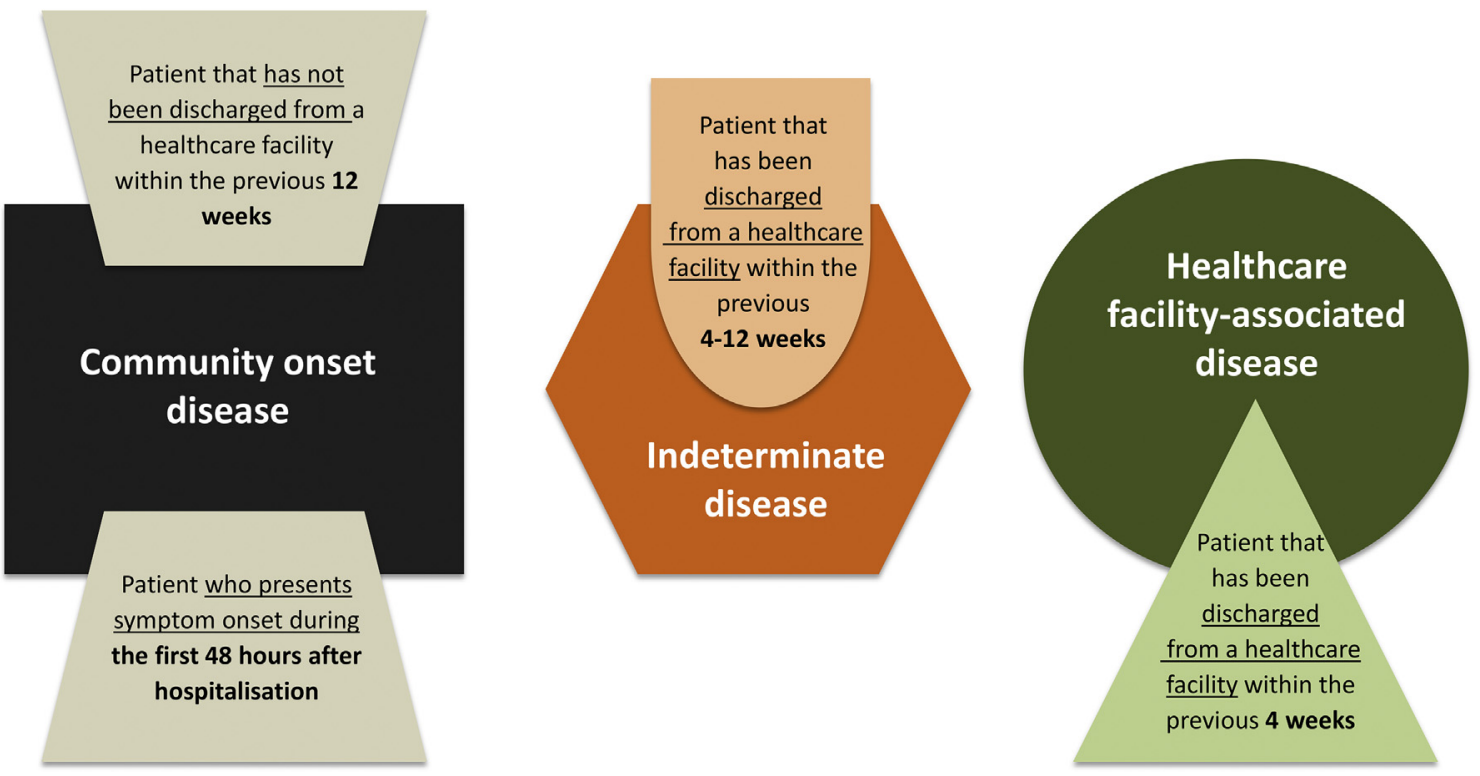

Fig. 2. Community onset CDI and healthcare facility-associated CDI definitions.

samples must be received in sterile close containers and kept at room temperature for a maximum of $2 \mathrm{~h}$, and therefore, specimens of dubious quality must be rejected [151].

The culture of samples is recognised as the most sensitive method for the detection of $C$. difficile, but its specificity for CDI is low because the rate of asymptomatic carriage of $C$. difficile among hospitalised patients is so high. This method is not clinically practical for routine diagnosis because it does not distinguish between toxigenic and non-toxigenic isolates and requires $24-48 \mathrm{~h}$ to obtain the first results [150]. However, stool culture testing permits the molecular typing of the isolated strains and antibiotic susceptibility determination, making it essential for epidemiological surveys $[8,150]$. Therefore, stool culture testing can be coupled with a cell cytotoxicity assay or EIA (enzyme immunoassay) to detect toxinproducing $C$. difficile strains (known as toxigenic cultures), resulting in increased specificity [150].

Since it was first proposed by George et al. in 1979 [133], cycloserine-cefoxitin fructose (CCF) has been the most commonly used medium for $C$. difficile isolation. The original formulation has been extensively modified, including the replacement of egg yolk by blood [150]. The addition of $1 \mathrm{~g} / \mathrm{L}$ of taurocholate, desoxycholate or cholate has also been shown to induce the germination of $C$. difficile spores when they are incorporated in CCF [152,153]. Sodium salt of cholic acid is more inexpensive than pure taurocholate but just as effective [150]. The concentration of the selective agents has also varied among studies, from $250 \mathrm{mg} / \mathrm{L}$ to $500 \mathrm{mg} / \mathrm{L}$ for cycloserine and from $8 \mathrm{mg} / \mathrm{L}$ to $16 \mathrm{mg} / \mathrm{L}$ for cefoxitin. Other modifications to improve this media have been proposed. Delmée et al. [154] included cefotaxime instead of cefoxitin, which increased the sensitivity and specificity of the medium. $C$. difficile colonies are easily recognised in this media when observed under the microscope: with an appearance similar to ground glass, they release an odour akin to horse manure and reveal a yellow-green fluorescence under ultraviolet illumination. Early identification of $C$. difficile colonies in this primary selective culture can be performed using an antigen latex agglutination assay. Latex particles are coated with IgG antibodies specific to $C$. difficile cell wall antigens. When the bacterium is present, the latex particles agglutinate into large visible clumps within 2 min. However, cross-reactions have been described, including with $C$. sordellii, Clostridium glycollicum and

\section{Clostridium bifermentans [155].}

Presently, several commercial selective media are available for the detection of $C$. difficile from stool specimens. The new chromogenic media seem to be effective as well as more rapid and sensitive than the classic selective media and have been shown to aid in the diagnosis of CDI [156-159]. However, pre-made agars are expensive and unaffordable for many research groups. Furthermore, they are used for the clinical recovery of $C$. difficile from faecal samples and not for the semi-quantification of viable spores [160].

Pre-treatment of samples with ethanol shock has been associated with an increase in sensitivity [161-164]. However, in the different studies conducted in our laboratory (unpublished data), ethanol shock or pre-heat treatment of samples does not improve the recovery of $C$. difficile from faecal or food samples. Rather, it seems that an increase in the time of enrichment is best for improving the sensitivity of the method. A bacterial competition in the enrichment broth has been observed [164]. In a previous study on carcasses and faecal samples [116], after 30 days of enrichment, different $C$. difficile types were identified, and colonies other than $C$. difficile were rarely present in the plate. However, the enrichment of samples is a time-consuming technique for laboratory purposes and might not be worth the slight increase in sensitivity observed.

Toxin detection is the most important clinical test [8]. It can be performed using cell lines to examine a stool filtrate (cell cytotoxicity assay) or by EIA [150]. Cell cytotoxicity is often considered the best standard test for identifying toxigenic $C$. difficile as it can detect toxins at picogram levels and is recognised as the most sensitive available test for the detection of toxin B [165]. A laboratory cell line (Vero, Hep2, fibroblasts, CHO or HeLa cells) is exposed to a filtrate of a stool suspension. If $C$. difficile toxins are present, a cytopathic effect is observed after 24-48 h (cell rounding via cytoskeleton disruption). The effect is mainly due to toxin $\mathrm{B}$, which is more cytotoxic than toxin A. The presence of toxigenic $C$. difficile can be confirmed if a specific antiserum (added later) reverses the effect on the cells. This method is very sensitive and specific but is relatively slow and requires the maintenance of cell lines. If the antiserum does not neutralise the cytopathic effect, which is observed in $21 \%$ of cases, the results are inconclusive [150].

EIA is rapid but less sensitive than the cell cytotoxicity assay [8], missing $40 \%$ of diagnoses [165]. However, it is easy to perform and 
does not require technical training or special equipment. EIA can detect both toxin A and toxin B and may also detect glutamate dehydrogenase $(\mathrm{GDH})$, a specific enzyme of $C$. difficile found in toxigenic and non-toxigenic isolates. $C$. difficile constitutively produces GDH in easily detectable levels, so tests based on GDH detection have good sensitivity (96\%-100\%). As GDH only identifies the bacterium and not the presence of toxins, the method is comparable with stool culture. Furthermore, it only takes 15-45 min and the cost is low (estimated at 8 USD); it can also be combined with a cell cytotoxicity assay, EIA for toxins, or culture with further toxin characterisation of the strains [165]. However, the results from GDH seem to differ based on the commercial kit used, and therefore, for some authors, this approach remains an interim recommendation [8]. EIA may be useful in laboratories without tissue culture facilities, but it must be combined with a positive culture. If the EIA results are negative and the culture test results are positive, it is recommended to isolate the strain from the plate and repeat EIA testing to determine if it is toxigenic [150]. Table 5 summarises the most-used tests for the diagnosis of $C$. difficile infection.

Delmée et al. (2001) [150] proposed the following scheme for the routine bacteriological diagnosis of CDI in humans. First, culture and toxin detection (by cytotoxicity assay or by EIA) should be performed directly from the stool specimen. If both tests are negative, a diagnosis of CDI is excluded. In contrast, if both are positive, the patient is diagnosed with $\mathrm{CDI}$ and requires immediate treatment. When the culture is positive but toxin detection is negative, an EIA test should be performed on several colonies removed from the culture plate. If the test is still negative, treatment is not necessary. If the test is positive, the patient should be considered positive for CDI. Finally, when the culture is negative but toxin detection is positive, a control specimen is requested and the culture must be repeated, which results in a patient testing positive for $C$. difficile in most cases. Repeat testing of patients who were previously positive as a "test of cure" is not appropriate [150].

Many studies have developed different real-time PCR (RT-PCR) methods for the detection of $C$. difficile toxin genes directly from stool samples, not only from humans $[166,167]$ but also from animals [168], and for the quantitative detection of $C$. difficile in hospital environmental samples [169]. Various automated RT-PCR systems are commercially available, intended as diagnostic tools for CDI. These systems include BD GeneOhm ${ }^{\mathrm{TM}}$ Cdiff (Becton Dickenson) ${ }^{2}$ and Xpert $^{\circledR} C$. difficile (Cepheid). ${ }^{3}$ These commercial RTPCRs have been shown to be rapid ( $<4 \mathrm{~h}$ for a result), sensitive and specific. Therefore, they have been largely proposed for the laboratory diagnosis of CDI [170-172]. In addition, a recent guide for the management of $C$. difficile infection in surgical patients suggests that PCR testing of perirectal swabs may be an efficient method for toxigenic $C$. difficile detection [173].

There are several other molecular genetic test systems commercially available for the identification of $C$. difficile from stool and culture samples. One example is Genotype Cdiff (Hain Lifescience), which is based on DNA strip technology. ${ }^{4}$ This system is based on DNA amplification, hybridisation and visualisation using the enzyme alkaline phosphatase. The results are visible in a colorimetric reaction. The test is rapid in detecting $C$. difficile, its toxins, deletions in the tcdC gene, and mutations in the gyrA gene that are associated with moxifloxacin resistance. However, these

\footnotetext{
2 https://www.bd.com/resource.aspx?IDX=17953.

3 http://www.cepheid.com/us/cepheid-solutions/clinical-ivd-tests/healthcareassociated-infections/xpert-c-difficile.

${ }^{4}$ http://www.hain-lifescience.de/en/products/microbiology/genotype-cdiff/ genotype-cdiff.html.
}

new technologies require considerable capital equipment, costly cartridges and experienced laboratory personnel. Furthermore, the results reported have not shown any significant improvement when compared with classic methods [150]. Therefore, some laboratories use these procedures to verify dubious results observed after rapid screening with other methods or to further process the samples for epidemiological purposes.

\section{C. difficile typing methods}

To characterise and compare the circulating strains and to identify emerging strains and those responsible for outbreaks worldwide, several typing methods have been applied. Table 6 summarises the available typing methods and their advantages and disadvantages. Lemée et al. (2004) [140] designed a multiplex PCR for the simultaneous identification and toxigenic type characterisation of $C$. difficile isolates. Several other studies have proposed different multiplex PCR primers and protocols not only to detect the genes encoding the major toxins $A$ and $B$ but also to detect binary toxin genes ( $c d t A$ and $c d t B$ ) and other deletions in the Paloc genes [174].

Pulsed-field gel electrophoresis $\left(\mathrm{PFGE}^{5}\right.$ ) and restriction enzyme analysis (REA) are widely used in the United States and Canada. PFGE was one of the first molecular methods used for C. difficile and other food-borne pathogens in North America [175]. The method uses restriction enzymes that infrequently cut (such as Smal or SacII) to cleave bacterial DNA at different restriction sites. The use of these infrequently cutting restriction enzymes limits the number of restriction fragments (to between 7 and 20) and ensures that they are relatively large [176]. Generally, the frequency of cutting is inversely proportional to the number of nucleotides in the recognition site [177]. In North America, the isolates are designated with NAP and a number (e.g., NAP1: North America Pulsotype 1) [178]. The technique separates the large fragments of DNA generated based on size using a pulsed-field electrophoresis gel with resulting electrophoresis patterns that are highly discriminatory. However, large amounts of high-molecular-weight DNA have to be read, making the process labour-intensive (Table 6). C. difficile typing based on REA is performed using total cellular DNA, which is digested with a frequently cutting restriction enzyme (HindIII), and the resulting fragments are resolved by classical agarose electrophoresis. This method was shown to be reproducible, highly discriminatory and universally applicable. However, the visual assessment of the large number of fragments in a single gel can be difficult and may be confounded by the presence of extrachromosomal DNA [175] (Table 6).

In Europe, $C$. difficile PCR-ribotyping has been recognised as the dominant typing method. PCR-ribotyping is based on the size variation of the 16S-23S rDNA intergenic spacer regions. A PCRribotype is defined as a group of strains that produce an identical band pattern. Therefore, a single band difference warrants a new ribotype [178]. Stubbs et al. (1999) [179] constructed a C. difficile PCR-ribotype reference library composed of 2030 isolates, with a total of 116 distinct types identified from environmental, hospital, community practitioner, veterinary and reference sources. The method was performed with agarose gel-based electrophoresis. Bidet et al. (1999) [180] improved the reading of the banding patterns by selecting a partial sequence of the rRNA genes (16S-23S) and the intergenic spacer region with a new set of primers located closer to this intergenic spacer region. The Public Health Laboratory

\footnotetext{
5 Pulsed-field Gel Electrophoresis (PFGE) | Pathogens and Protocols | PulseNet | CDC [WWW Document], n.d. URL http://www.cdc.gov/pulsenet/pathogens/pfge. html (accessed 6.18.15).
} 
Table 5

Laboratory test for C. difficile.

\begin{tabular}{|c|c|c|c|c|c|c|c|}
\hline $\begin{array}{l}\text { C. difficile } \\
\text { detection }\end{array}$ & Test & Objective & Characteristics & Confirmation & Advantages & Disadvantages & Study \\
\hline \multirow[t]{2}{*}{$\begin{array}{l}\text { Toxin/enzyme } \\
\text { detection }\end{array}$} & $\begin{array}{l}\text { Cell cytotoxicity } \\
\text { assay }\end{array}$ & $\begin{array}{l}\text { Considered the best } \\
\text { standard test for } \\
\text { identifying toxigenic } \\
\text { C. difficile }\end{array}$ & $\begin{array}{l}\text { A laboratory cell line (Vero, } \\
\text { Hep2, fibroblast, CHO or } \\
\text { HeLa cells) is exposed to a } \\
\text { filtrate of a stool suspension } \\
\text { If } C \text {. difficile toxins are } \\
\text { present, a cytopathic effect } \\
\text { is observed after } 24-48 \text { h } \\
\text { (cell rounding via } \\
\text { cytoskeleton disruption) } \\
\text { The effect is mainly due to } \\
\text { toxin B (which is more } \\
\text { cytotoxic than toxin A) }\end{array}$ & $\begin{array}{l}\text { The presence of toxigenic } C \text {. } \\
\text { difficile can be confirmed if } \\
\text { a specific antiserum (added } \\
\text { later) reverses the effect on } \\
\text { the cells }\end{array}$ & $\begin{array}{l}\text { It can detect toxins at } \\
\text { picogram levels } \\
\text { Most sensitive available } \\
\text { test for detection of toxin B }\end{array}$ & $\begin{array}{l}\text { Relatively slows and } \\
\text { requires the maintenance } \\
\text { of cell lines. } \\
\text { If the antiserum does not } \\
\text { neutralise the cytopathic } \\
\text { effect, which is observed in } \\
21 \% \text { of cases, the results are } \\
\text { inconclusive }\end{array}$ & {$[8,165,166]$} \\
\hline & $\begin{array}{l}\text { Enzyme } \\
\text { immunoassay } \\
\text { (EIA) }\end{array}$ & 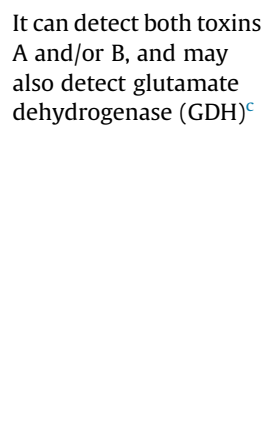 & $\begin{array}{l}\text { C. difficile constitutively } \\
\text { produces GDH in easily } \\
\text { detectable levels, but only } \\
\text { identifies the bacterium } \\
\text { and not the presence of } \\
\text { toxins (the method is } \\
\text { comparable with stool } \\
\text { culture) }\end{array}$ & $\begin{array}{l}\text { The method can be } \\
\text { combined with cell } \\
\text { cytotoxicity assay, EIA for } \\
\text { toxins, or culture with } \\
\text { further toxin } \\
\text { characterisation of the } \\
\text { strains } \\
\text { If EIA results are negative } \\
\text { and culture testing results } \\
\text { are positive, it is } \\
\text { recommended to isolate the } \\
\text { strain from the plate and } \\
\text { repeat EIA testing to } \\
\text { determine if it is toxigenic }\end{array}$ & $\begin{array}{l}\text { Rapid ( } 15-45 \text { min) } \\
\text { Low cost (estimated at } 8 \\
\text { USD) } \\
\text { Easy to perform and does } \\
\text { not require technical } \\
\text { training or special } \\
\text { equipment } \\
\text { Good sensitivity for } \\
\text { detection of GDH ( } 96 \% \\
-100 \% \text { ) } \\
\text { Useful in laboratories } \\
\text { without culture facilities }\end{array}$ & $\begin{array}{l}\text { Less sensitive than the cell } \\
\text { cytotoxicity assay missing } \\
40 \% \text { of diagnosis } \\
\text { Results seem to differ based } \\
\text { on the commercial kit used } \\
\text { It must be combined with a } \\
\text { positive culture) }\end{array}$ & \\
\hline Culture & Stool culture & $\begin{array}{l}\text { It permits molecular } \\
\text { typing of the isolated } \\
\text { strains and antibiotic } \\
\text { susceptibility } \\
\text { determination } \\
\text { (essential for } \\
\text { epidemiological } \\
\text { surveys) }\end{array}$ & $\begin{array}{l}\text { Cycloserine-cefoxitin } \\
\text { fructose (CCF) has been the } \\
\text { most commonly used } \\
\text { medium for C. difficile } \\
\text { isolation. The medium } \\
\text { includes egg-yolk or blood } \\
\text { and taurocholate, } \\
\text { desoxycholate or cholate, } \\
\text { which has been shown to } \\
\text { induce germination of } \\
\text { spores. } \\
\text { Presently, several } \\
\text { commercial selective media } \\
\text { are available. The new } \\
\text { chromogenic media improve } \\
\text { the recovery the bacterium. } \\
\text { Pre-treatment of samples } \\
\text { with ethanol shock has } \\
\text { been associated with an } \\
\text { increase in sensitivity }\end{array}$ & $\begin{array}{l}\text { Molecular typing of the } \\
\text { strains }\end{array}$ & $\begin{array}{l}\text { Most sensitive method for } \\
\text { detection of } C \text {. difficile } \\
\text { Pre-made agars are used for } \\
\text { the clinical recovery of } C \text {. } \\
\text { difficile from faecal samples } \\
\text { and not for the semi- } \\
\text { quantification of viable } \\
\text { spores }\end{array}$ & $\begin{array}{l}\text { Low specificity for } \mathrm{CDI}^{\mathrm{d}} \\
\text { Not clinically practical for } \\
\text { routine diagnosis: } \\
\text { Slow }(24-48 \mathrm{~h}) \text { and its not } \\
\text { give information about } \\
\text { toxin production }\end{array}$ & {$[8,150,166-170]$} \\
\hline $\begin{array}{l}\text { Molecular } \\
\text { methods }\end{array}$ & $\begin{array}{l}\text { Real Time PCR } \\
\text { (RT-PCR) }\end{array}$ & $\begin{array}{l}\text { Detection of } C \text {. difficile } \\
\text { toxin genes directly } \\
\text { from stool samples }\end{array}$ & $\begin{array}{l}\text { BD GeneOhmTM Cdiff } \\
\text { (Becton Dickenson) }^{\mathrm{a}} \\
\left.\text { Xpert }^{\circledR} \text { C. difficile (Cepheid) }\right)^{\mathrm{b}}\end{array}$ & $\begin{array}{l}\text { Culture with further } \\
\text { characterisation of the } \\
\text { strains }\end{array}$ & $\begin{array}{l}\text { Rapid ( }<4 \mathrm{~h} \text { for a result), } \\
\text { sensitive and specific }\end{array}$ & $\begin{array}{l}\text { Expensive } \\
\text { Requires technical training } \\
\text { and special equipment }\end{array}$ & [171-173] \\
\hline
\end{tabular}

b http://www.cepheid.com/us/cepheid-solutions/clinical-ivd-tests/healthcare-associated-infections/xpert-c-difficile.

c Specific enzyme of $C$. difficile produced in in both toxigenic and non-toxigenic isolates.

d Low specificity for $C$. difficile infection (CDI) because the rate of asymptomatic carriage of $C$. difficile among hospitalised patients is so high.

e They have been largely proposed for laboratory diagnosis of CDI but also for quantitative detection of $C$. difficile in hospital environmental samples. 


\begin{tabular}{|c|c|c|c|c|}
\hline Method & Characteristics & Advantages & Disadvantages & Reference \\
\hline Multiplex PCR & $\begin{array}{l}\text { The PCR can target: } \\
\text { - } t p i \text { housekeeping gene } \\
\text { - an internal fragment of the toxin B ( } t c d B \text { gene) } \\
\text { - the } 3^{\prime} \text { region, deleted or not, of the toxin A ( } t c d A \text { gene) } \\
\text { - binary toxin genes ( } c d t A \text { and } c d t B) \\
\text { - Other deletions in the Paloc genes }\end{array}$ & Low cost & Process labour-intensive & {$[140,174]$} \\
\hline $\begin{array}{l}\text { Pulsed-field gel } \\
\text { electrophoresis (PFGE) }\end{array}$ & $\begin{array}{l}\text { The method uses infrequently-cutting restriction } \\
\text { enzymes (like SmaI or SacII) to cut bacterial DNA at } \\
\text { different restriction sites }\end{array}$ & Highly discriminatory & $\begin{array}{l}\text { Process labour-intensive } \\
\text { Difficulty of lysing spores } \\
\text { Difficulty of interpreting results and the inter-laboratory } \\
\text { exchange of the results } \\
\text { Equipment and time required }\end{array}$ & {$[175,176]$} \\
\hline $\begin{array}{l}\text { Restriction enzyme } \\
\text { analysis } \\
\text { (REA) }\end{array}$ & $\begin{array}{l}\text { The method uses frequently-cutting restriction enzymes } \\
\text { (HindIII) to cut total cellular DNA at different restriction } \\
\text { sites }\end{array}$ & $\begin{array}{l}\text { Reproducible and highly discriminatory power } \\
\text { Universally applicable }\end{array}$ & $\begin{array}{l}\text { Difficulty of interpreting results and the inter-laboratory } \\
\text { exchange of the } \\
\text { results }\end{array}$ & [175] \\
\hline PCR-ribotyping & $\begin{array}{l}\text { A PCR-ribotype is defined as a group of strains that } \\
\text { produce an identical band pattern based on the size } \\
\text { variation of the } 16 \mathrm{~S}-23 \mathrm{~S} \text { rDNA intergenic spacer regions }\end{array}$ & $\begin{array}{l}\text { Dominant typing method } \\
\text { Inter-laboratory comparisons easy if standard } \\
\text { nomenclature is available or use of Webribo database }\end{array}$ & $\begin{array}{l}\text { Time intensive } \\
\text { Equipment and material costs } \\
\text { Technical training required } \\
\text { Inter-laboratory comparisons difficult if standard } \\
\text { nomenclature is not available }\end{array}$ & {$[178,182]$} \\
\hline QIAxcel $^{\mathbb{B}}$ system & $\begin{array}{l}\text { For } C \text {. difficile ribotyping, the detection of } t c d C 18 \text { bp } \\
\text { deletion, and toxin gene detection } \\
\text { Based on an automated electrophoresis platform }\end{array}$ & $\begin{array}{l}\text { Reduce the cost } \\
\text { of hands-on time } \\
\text { Allows analysis of up to } 96 \text { samples per run }\end{array}$ & $\begin{array}{l}\text { Cost of the cartridges and equipment } \\
\text { Limited sensitivity and discriminatory power (cannot } \\
\text { distinguish between closely related PCR-ribotypes) }\end{array}$ & [184] \\
\hline $\begin{array}{l}\text { Serotyping } \\
\text { - by slide agglutination } \\
\text { - by polyacrylamide gel } \\
\text { electrophoresis } \\
\text { - by ELISA }\end{array}$ & $\begin{array}{l}\text { The method distinguishes variations in C. difficile strains } \\
\text { based on bacteria surface antigens }\end{array}$ & $\begin{array}{l}\text { Good correlation between methods } \\
\text { Reproducible, Rapid and reliable } \\
\text { Inter-laboratory comparisons easy }\end{array}$ & $\begin{array}{l}\text { Cross-agglutination caused by flagellar antigens (totally } \\
\text { suppressed by ELISA) }\end{array}$ & {$[185,186]$} \\
\hline $\begin{array}{l}\text { Surface-layer protein } \\
\text { A gene sequence } \\
\text { typing (slpAST) }\end{array}$ & $\begin{array}{l}\text { Sequencing of } \operatorname{slpA} \text { gene, which encodes for a surface } \\
\text { immuno protein Layer (S-layer) }\end{array}$ & $\begin{array}{l}\text { Good discriminatory power } \\
\text { It can be applied to direct typing (without culture) from } \\
\text { DNA stool specimens }\end{array}$ & $\begin{array}{l}\text { It has been showed that } C \text {. difficile genotype is no } \\
\text { predictive of antigenic types }\end{array}$ & [187-189] \\
\hline $\begin{array}{l}\text { Repetitive sequence-based } \\
\text { PCR typing (rep-PCR) }\end{array}$ & $\begin{array}{l}\text { Specific repetitive PCR-primers complement the short } \\
\text { repetitive sequences dispersed the bacterial genome } \\
\text { The amplified DNA fragments provide a genomic } \\
\text { fingerprint that can be employed for subspecies } \\
\text { discrimination }\end{array}$ & $\begin{array}{l}\text { Automated rep-PCR with a higher discriminatory power } \\
\text { than traditional PCR-ribotyping }\end{array}$ & $\begin{array}{l}\text { Requires visual interpretation and technical skills } \\
\text { Inter-laboratory reproducibility has not been } \\
\text { demonstrated }\end{array}$ & [190-192] \\
\hline $\begin{array}{l}\text { Random amplified } \\
\text { polymorphic DNA } \\
\text { (RAPD) }\end{array}$ & $\begin{array}{l}\text { Random amplification of DNA segments by PCR reaction } \\
\text { using a single primer of arbitrary nucleotide sequence }\end{array}$ & $\begin{array}{l}\text { Inexpensive } \\
\text { Does not require any specific knowledge of the DNA } \\
\text { sequence }\end{array}$ & $\begin{array}{l}\text { Must be combined with PCR-ribotyping to obtain } \\
\text { higher discriminatory power }\end{array}$ & {$[193,194]$} \\
\hline $\begin{array}{l}\text { Amplified fragment length } \\
\text { polymorphism } \\
\text { (AFLP) }\end{array}$ & $\begin{array}{l}\text { Genomic DNA is totally digested with two restriction } \\
\text { enzymes. This step is followed by ligation of double- } \\
\text { stranded oligonucleotide adaptors to the sticky ends of } \\
\text { the restriction fragments followed by amplified by PCR }\end{array}$ & Low cost & $\begin{array}{l}\text { Suboptimal reproducibility (variation in the precision } \\
\text { of sizing of fragments) } \\
\text { Limited application in C. difficile typing }\end{array}$ & [195] \\
\hline Toxinotyping & $\begin{array}{l}\text { Polymerase chain reaction-restriction fragment length } \\
\text { polymorphism based method for differentiating strains } \\
\text { according to changes in their toxin genes when } \\
\text { compared to the reference VPI } 10463 \text { strain }\end{array}$ & $\begin{array}{l}\text { Results of toxinotyping and PCR-ribotyping correlated } \\
\text { well }\end{array}$ & Requires technical skills & [175] \\
\hline $\begin{array}{l}\text { Multilocus sequence typing } \\
\text { (MLST) }\end{array}$ & $\begin{array}{l}\text { The sequences of internal fragments of housekeeping } \\
\text { genes (usually seven) are used to characterise the strains }\end{array}$ & Inter-laboratory comparisons easy & $\begin{array}{l}\text { Time-consuming (several days) } \\
\text { Costly and laborious technique } \\
\text { Requires specific technical skills }\end{array}$ & {$[199,200]$} \\
\hline $\begin{array}{l}\text { Multilocus variable number } \\
\text { tandem repeat analysis } \\
\text { (MLVA) }\end{array}$ & $\begin{array}{l}\text { The method utilizes the naturally occurring variation in } \\
\text { the number of tandem repeated DNA sequences found } \\
\text { in many different loci in the genome. The different lengths } \\
\text { of variable number of tandem repeats (VNTR) regions } \\
\text { are determined to distinguish among strains }\end{array}$ & $\begin{array}{l}\text { High discriminatory power which allows tracking of } \\
\text { outbreaks and determining phylogenetic relationships }\end{array}$ & $\begin{array}{l}\text { Time-consuming } \\
\text { Costly and laborious technique } \\
\text { Requires specific technical skills } \\
\text { Inter-laboratory comparisons difficult }\end{array}$ & {$[175,201]$} \\
\hline $\begin{array}{l}\text { Whole genome sequencing } \\
\text { (WGS) }\end{array}$ & $\begin{array}{l}\text { The method reveals the complete DNA of the bacterium } \\
\text { at a single time }\end{array}$ & $\begin{array}{l}\text { Provides the most comprehensive collection of an } \\
\text { individual's genetic variation } \\
\text { Increasingly low cost }\end{array}$ & $\begin{array}{l}\text { Method still under development } \\
\text { The large amount of data requires technical skills for } \\
\text { further processing and analysis }\end{array}$ & [203] \\
\hline
\end{tabular}

${ }^{\text {a }}$ Species species-interspecific fragment of the triose phosphate isomerase (tpi) housekeeping gene. 
Service Anaerobe Reference Unit, Cardiff (UK) has established a ribotyping nomenclature reference database for $C$. difficile. This nomenclature is designated by a three-digit number starting from 001 (ex. PCR-ribotype 027). Currently, the collection of existing PCR-ribotypes and the assignment of new ones is performed by the Health Protection Agency-funded $C$. difficile Ribotype Network (CDRN) in Leeds (UK), which has more than 600 different PCRribotypes in the CDRN database [181]. However, in many laboratories, the standard nomenclature is not always available and a local nomenclature is used, making inter-laboratory comparisons difficult [178] (Table 6). Indra et al. (2008) [182] developed a $C$. difficile sequencer-based PCR-ribotyping method based on capillary gel electrophoresis that was proposed in order to solve the problems associated with inter-laboratory comparisons of typing results and to make PCR-ribotyping less time-intensive (Table 6). PCR amplification was performed using a fluorescent label in one of the primers, and the amplicon sizes were determined using an $\mathrm{ABI}$ genetic analyser [175]. A database and web-based software programme was created that allows the analysis and comparison of $C$. difficile capillary-sequencer-based PCR-ribotyping data by simply uploading sequencer data files. ${ }^{6}$ Janezic et al. (2011) [183] described a modification to PCR-ribotyping that enables the detection of $C$. difficile in stool samples within hours. The designed primers were located partially within the $C$. difficile 16S-23S rRNA intergenic spacer regions and partially within $16 \mathrm{~S}$ (forward primer) and $23 \mathrm{~S}$ (reverse primer).

The QIAxcel ${ }^{\circledR}$ system has been proposed as a new method for $C$. difficile ribotyping, the detection of tcdC18 bp deletion, and toxin gene detection (toxin A, toxin B and binary toxin CDT genes). ${ }^{7}$ QIAxcel is based on an automated electrophoresis platform that processes samples in batches of 12 and allows the analysis of up to 96 samples per run. The system does not require the use of fluorescein-labelled primers and displays the data as both a gelview format and an electropherogram. The system has the potential to reduce the cost of PCR-ribotyping by drastically reducing the hands-on time. The major costs are the purchase of cartridges, the setup of the QIAxcel system hardware, and the BioCalculator analysis. However, the method has limited sensitivity and discriminatory power. It cannot clearly distinguish between closely related ribotypes, such as 027 and 176 [184].

Serotyping distinguishes variations in C. difficile strains based on the bacterial surface antigens. Serogrouping by slide agglutination and by polyacrylamide gel electrophoresis have both been traditionally accepted as practical in routine typing [185]. Both methods have shown a good correlation in results and allow the differentiation of 10 major serogroups (A, B, C, D, F, G, H, I, K and X). Specific profiles have been associated with each of the 10 serogroups except for serogroup A. Strains from serogroup A have a common flagellar antigen that is responsible for cross-agglutination. The shearing of the flagella allows the differentiation of 12 different subgroups of serogroup A. Delmée et al. (1993) [186] used an enzyme-linked immunosorbent assay (ELISA) with antisera specific for the $10 \mathrm{C}$. difficile serogroups ( $\mathrm{A} 1, \mathrm{~B}, \mathrm{C}, \mathrm{D}, \mathrm{F}, \mathrm{G}, \mathrm{H}, \mathrm{I}, \mathrm{K}, \mathrm{X}$ ) and the 12 serogroups within serogroup A (A2 to A12) for the serogrouping of $C$. difficile colonies for 314 positive faecal samples. The authors found that ELISA was a rapid and reliable method for $C$. difficile serotyping and that cross-agglutination caused by flagellar antigens in the slide agglutination method is totally suppressed by ELISA.

Surface-layer protein A gene sequence typing ( $\operatorname{slpAST}$ ) has also been described for $C$. difficile characterisation. $C$. difficile has a surface immuno-protein Layer (S-layer) encoded by the $\operatorname{slp} A$ gene, and the typing of isolates is performed by the sequencing of this $\operatorname{slp} A$ gene. It can also be used for direct typing from DNA stool specimens without culture [187]. This method has been reported as a discriminative tool for $C$. difficile characterisation [188]. However, Dingle et al. (2013) [189] showed that the C. difficile genotype was not predictive of antigenic types. Therefore, S-layer typing could be useful for explaining the temporal changes and geographic differences in the epidemiology of CDI as well as the way in which isolates (and antigens) are selected for inclusion in $C$. difficile vaccines [189].

Repetitive sequence-based PCR typing (rep-PCR) is another method proposed for the characterisation of $C$. difficile strains [190]. Bacterial genomes contain multiple dispersed short repetitive sequences separating longer single-copy DNA sequences. Specific repetitive PCR primers complement these repetitive sequences, and the amplified DNA fragments provide a genomic fingerprint that can be employed for subspecies discrimination [191]. The DiversiLab system ${ }^{8}$ is an automated rep-PCR typing method that has a high discriminatory power when compared to traditional PCRribotyping. However, this method requires the visual interpretation of rep-PCR fingerprint patterns and technical skills. Furthermore, interlaboratory reproducibility for this method must be demonstrated prior to its use for $C$. difficile surveillance [192].

Random amplified polymorphic DNA (RAPD) analysis is the 'random amplification' of DNA segments by PCR reaction using a single primer consisting of an arbitrary nucleotide sequence. RAPD is an inexpensive and powerful typing method and does not require any specific knowledge of the DNA sequence of the target microorganism. The amplification of a segment of DNA will be performed depending on positions that are complementary to the primer sequence. Green et al. (2011) [193] used PCR-ribotyping in conjunction with RAPD to further categorise different $C$. difficile types within defined PCR-ribotypes and therefore obtained a higher discriminatory power than either of the methods used alone. Barbut et al. (1993) [194] evaluated genomic fingerprinting of $C$. difficile strains using RAPD and suggested that this method could be an additional valuable tool for epidemiological studies.

In the amplified fragment length polymorphism (AFLP) technique, a small amount of purified genomic DNA is totally digested with two restriction enzymes, one with an average cutting frequency and the other with a higher cutting frequency. This step is followed by the ligation of double-stranded oligonucleotide adaptors to the sticky ends of the restriction fragments, followed by PCR amplification. After final amplification, the selectively amplified fragments are separated by gel electrophoresis and comparison of banding patterns is typically achieved using dedicated fingerprinting analysis software. AFPL has a relatively low cost, but variation in the precision of the sizing of fragments has been observed, leading to suboptimal reproducibility [195]. This method has seen limited application in C. difficile typing. Klaassen et al. (2002) [196] reported that AFLP analysis yielded high-resolution and highly reproducible fingerprinting patterns in a short time period $(24 \mathrm{~h})$ to evaluate epidemiological relatedness among hospital $C$. difficile isolates. A further study showed that AFLP is better able to discriminate between $C$. difficile reference strains (most of them toxin $\mathrm{A}+$, toxin $\mathrm{B}+$ ) than PCR-ribotyping. However, for toxin A-, toxin B + isolates, both methods yielded similar results [138].

Toxinotyping is a polymerase chain reaction-restriction fragment length polymorphism (PCR-RFLP) based method for differentiating $C$. difficile strains according to changes in their toxin genes

\footnotetext{
${ }^{6}$ https://webribo.ages.at/.

7 https://www.qiagen.com/be/products/catalog/automated-solutions/detectionand-analysis/qiaxcel-advanced-system/.
}

${ }^{8}$ http://www.biomerieux-diagnostics.com/diversilab. 
when compared to the reference strain VPI 10463. Strains belonging to the same toxinotype have identical changes in the PaLoc region. Toxinotyping is performed by PCR amplification and restriction enzyme digestion of 10 regions of the PaLoc [175]. Currently, 31 different toxinotypes are identified and designated by Roman numerals from I to XXXII. Strains with toxin genes similar to VPI 10463 are classified as toxinotype 0 . A total of 12 out of 20 toxinotypes with variant strains produce binary toxin, while most of the toxinotypes not producing binary toxin have toxin genes very similar to the reference strain, VPI $10463^{9}$. In this context, only one strain resembling VPI 10463 and positive for CDT has been previously described [197]. Toxinotype XXXII has been recently reported and corresponds to a new type of $C$. difficile strain (toxin $\mathrm{A}-, \mathrm{B}+$, CDT-) that completely lacks the $t c d A$ gene and has an atypical organisation of the PaLoc integration site [198].

Multilocus sequence typing (MLST) analysis uses the sequences of internal fragments of housekeeping genes (usually seven) to characterise the strains. The internal fragments of each gene (450-500 bp) are sequenced on both strands using an automated DNA sequencer. For each housekeeping gene, the different sequences present within a bacterial species are assigned as distinct alleles, and for each isolate, the alleles at each of the seven loci define the allelic profile or sequence type (ST). The data obtained are unambiguous, and the allelic profiles of the isolates can easily be compared to those in a large central database and therefore can be compared between laboratories ${ }^{10}$. There are two MLST databases available for $C$. difficile, each adapted to a different typing scheme: the first is organised according to the scheme described by Griffiths et al. (2010) [199], which is performed with the housekeeping genes $a d k, a t p, d x r, \operatorname{rec} A, \operatorname{sod} A, \operatorname{tpi}$ and $g l y A^{11}$; and the second is organised according to the scheme described by Lemée et al. (2004) [200], which is performed with the housekeeping genes aroE, dutA, gmk, groEL, recA, sodA and tpi. ${ }^{12}$ The primary problem with MLST is the time-consuming nature of the method, with the completion of analysis taking several days. In addition, MLST is a relatively costly and laborious technique that requires specific technical skills.

Multilocus variable-number tandem-repeat analysis (MLVA) has been suggested to have higher discriminatory power than other typing methods for investigating the relatedness between $C$. difficile strains [201]. It has been widely used in medical microbiology as an alternative or complement to other typing techniques such as PFGE, rep-PCR or MLST [202]. MLVA utilizes the naturally occurring variation in the number of tandem repeat DNA sequences found in many different loci in the genome. Therefore, the lengths of the variable number of tandem repeats (VNTR) regions are determined to distinguish among the strains. The technique is achieved by a multiplex PCR assay (with primers designed to target different VNTR regions in the genome) and visualised by electrophoresis or automated fragment analysis on a sequencer. The product size is used to calculate the number of repeat units of each locus. The calculated numbers of repeats of the VNTR loci (alleles) are combined, and this provides the MLVA profile. Each unique MLVA profile is given an MLVA type designation. The MLVA profile can be used for the comparison and clustering of the bacterial strains. ${ }^{13}$ Compared with traditional PCR ribotyping, MLVA has increased discriminatory power, which allows for the more efficient tracking of outbreaks and has the potential to determine phylogenetic

\footnotetext{
9 http://www.mf.uni-mb.si/tox/.

10 http://pubmlst.org/general.shtml.

11 http://pubmlst.org/cdifficile/.

12 http://www.pasteur.fr/recherche/genopole/PF8/mlst/Cdifficile2.html.

13 http://www.mlva.net/.
}

relationships. In addition, MLVA produces digital data with a decreased turnaround time [175].

Whole genome sequencing (WGS) reveals the complete DNA of an organism at a single time and provides the most comprehensive collection of an individual's genetic variation [203]. Sanger sequencing and subsequently Roche 454 and Illumina nextgeneration sequencing technologies have been applied to study the evolutionary dynamics of $C$. difficile [175] at increasingly low cost [203]. Recent studies have applied WGS to determine the epidemiological relationships between $C$. difficile strains in healthcare settings or in the scientific community employing WGS [204]. Although the method is still under development and the large amount of data obtained requires technical skills for further processing and analysis, it is very probable that in the near future, WGS will replace all other current typing techniques.

Killgore et al. (2007) [205] compared seven different techniques (REA, PGE, PCR-ribotyping, MLST, MLVA, AFLP and slpAST) for epidemic $C$. difficile strain typing. They found that all methods appeared to be adequate for detecting an outbreak strain in a particular institution. However, REA or MLVA showed the highest level of discrimination between strains, and they seem to be the most recommended methods to track outbreak strains geographically. However, as neither of the techniques are widely used and little data are available, there is currently no method with proven interlaboratory reproducibility for inter-institutional $C$. difficile tracking.

\section{High-throughput sequencing analysis and CDI}

$16 S$ metagenetics is a culture-independent strategy allowing the identification of bacterial populations present in a large panel of samples. It has been recently introduced to investigate the intestinal microbiota of healthy patients and patients suffering CDI. In the last year, most of the studies reported bacteria at the phylum and class level, but higher taxonomic resolution may reveal more differences in the population structure [206]. Preliminary results have shown that one of the taxa found in high proportions in patients with CDI is Proteobacteria, while Bacteroidetes proportions are lower in infected patients [207]. In this context, one study has proposed the use of Bacteroidetes and Firmicutes as probiotics to treat CDI [208]. However, the few available data regarding alterations to the intestinal microbiota of patients with CDI has been obtained in different patient conditions (age, antibiotic treatment, hospitalisation), which explains the high amount of variability between the studies. Despite this limitation, further studies exploring the diversity of the gut microbiota in CDI patients will be critical for further understanding the pathogenesis of $C$. difficile and for developing new approaches for the treatment and prophylaxis of the infection. In addition, recent studies in humans and animals have shown that many of the sequences were not identical to sequence entries present in the available databases $[209,210]$. Furthermore, among the sequences identical to known entries, the species name was seldom taxonomically defined. As previously reported, these findings underline the complexity of the gut microbiota, stressing the need for further research on taxonomy and functional microbiology [207].

\section{Conclusions and perspectives}

Eighty years after its discovery, $C$. difficile continues to be the focus of attention in hospitals and an important topic for many research groups worldwide. Recognised as the leading cause of nosocomial antibiotic-associated diarrhoea, the incidence of CDI remains high and in some years has increased, despite the efforts to improve prevention and reduce the spread of the bacterium in 
healthcare settings. Outside of Europe and America, the incidence of CDI infection is also rising. The major research studies of the last decade have been focused on the control of the spread of the bacterium, the rapid diagnosis of CDI, and the efficacy of treatment and recurrence prevention. Different guidelines have been designed to improve the management of the infection. Diagnosis must consider both clinical and laboratory findings. Laboratory tests must be rapid and sensitive; therefore, stool culture is not clinically practical. However, the isolation of the strain is necessary for epidemiological studies. There is a need for highly discriminatory typing methods, and results should be comparable between laboratories. One potential alternative in the near future is whole genome sequencing, now considered as the next-generation typing tool.

The investigation of the gut's microbial communities by new metagenetic analyses will allow researchers to discern whether any alteration of the gut microbiota composition can favour $C$. difficile colonisation, as well as the microbes responsible for rendering individuals less susceptible to the infection. This approach will be critical in the future to further understand the pathogenesis of $C$. difficile and to develop new successful prevention and treatment measures.

\section{References}

[1] S. Fridkin, J. Baggs, R. Fagan, S. Magill, L.A. Pollack, P. Malpiedi, et al., Vita signs: improving antibiotic use among hospitalized patients, MMWR Morb. Mortal. Wkly. Rep. 63 (2014) 194-200.

[2] C. Rodriguez, N. Korsak, B. Taminiau, V. Avesani, J. Van Broeck, M. Delmée, et al., Clostridium difficile infection in elderly nursing home residents, Anaerobe 30 (2014) 184-187.

[3] E. Borali, G. Ortisi, C. Moretti, E.F. Stacul, R Lipreri, G.P. Gesu, et al., Community-acquired Clostridium difficile infection in children: a retrospective study, Dig. Liver Dis. 47 (2015) 842-846.

[4] E.J. Kuijper, B. Coignard, P. Tüll, ESCMID study group for C. difficile, EU member States, european centre for disease prevention and control. Emergence of Clostridium difficile-associated disease in North America and Europe, Clin. Microbiol. Infect. 12 (Suppl 6) (2006) 2-18.

[5] E.J. Kuijper, F. Barbut, J.S. Brazier, N. Kleinkauf, T. Eckmanns, M.L. Lambert, et al., Update of C. difficile infection due to PCR-ribotype 027 in Europe, Eurosurveillance 2008 (13) (2008) 31.

[6] A. Goorhuis, D. Bakker, J. Corver, S.B. Debast, C. Harmanus, D.W. Notermans, et al., Emergence of Clostridium difficile infection due to a new hypervirulent strain, polymerase chain reaction ribotype 078, Clin. Infect. Dis. 47 (2008) 1162-1170.

[7] J. Freeman, J. Vernon, K. Morris, S. Nicholson, S. Todhunter, C. Longshaw, et al., Pan-European longitudinal surveillance of antibiotic resistance among prevalent Clostridium difficile ribotypes, Clin. Microbiol. Infect. 21 (248) (2015) e9-e16.

[8] S.H. Cohen, D.N. Gerding, S. Johnson, C.P. Kelly, V.G. Loo, L.C. McDonald, et al. Clinical practice guidelines for Clostridium difficile infection in adults: 2010 update by the Society for healthcare epidemiology of America (SHEA) and the Infectious Diseases Society of America (IDSA), Infect. Control Hosp. Epidemiol. 31 (2010) 431-455.

[9] I.C. Hall, E. O'Toole, Intestinal flora in new-born infants with a description of a new pathogenic anaerobe, Bacillus difficilis, Am. J. Dis. Child. 49 (1935).

[10] M.L. Snyder, Further studies on Bacillus difficilis (Hall and O'Toole), J. Infect. Dis. 60 (1937) 223-231.

[11] A. Prévot, Etudes de systematic bacterienne, Ann. Inst. Pasteur 61 (1938) $72-91$.

[12] V. Skerman, V. McGowan, P. Sneath, Approved Lists of Bacterial Names (Amended), ASM Press, Washington (DC), 1989.

[13] M.L. Snyder, The normal fecal flora of infants between two weeks and one year of age, J. Infect Dis 1940 (66) (1940) 1-16.

[14] L.D. Smith, E.O. King, Occurrence of Clostridium difficile in infections of man J. Bacteriol. 84 (1962) 65-67.

[15] D. Danielsson, D. Lambe, S. Persson, The inmune response in patient to an infection with Bacteroides fragilis spp. fragilis and Clostridium difficile, Acta Path Microbiol. Scand. 80 (1972) 709-712.

[16] S. Gorbach, K. Menda, H. Thadepalli, L. Keith, Anaerobic flora of the cervix in healthy women, Am. J. Obstet. Gynecol. 15 (1973) 1053-1055.

[17] V. Sutter, S. Finegold, The effect of antimicrobial agents on human fecal flora: studies with cephamexin, cyclacillin and clindamicyn, in: F. Skinner, J.G. Carr (Eds.), The Normal Microbial Flora of Man, Academic Press, London, 1974, pp. 229-240.

[18] S. Gorbach, H. Thadepalli, Isolation of Clostridium in humans infections: evaluation of 114 cases, J. Infect. Dis. 131 (1975) S81-S85.
[19] S. Hafiz, R.S. Morton, M.G. Mcentegart, S.A. Waitkins, Clostridium difficile in the urogenital tract of males and females, Lancet 305 (1975) 420-421.

[20] S. Hafiz, C. Oakley, Clostridium difficile: isolation and characteristics, J. Med. Microbiol. 9 (1976) 129-136.

[21] W.L. George, V.L. Sutter, S.M. Finegold, Antimicrobial agent-induced diarrhea-a bacterial disease, J. Infect. Dis. 136 (1977) 822-828.

[22] D. Hamre, G. Rake, C. McKee, H. MacPhillamy, The toxicity of penicillin as prepared for clinical use, Am. J. Med. Sci. 206 (1943) 642.

[23] R.H. Green, The association of viral activation with penicillin toxicity in guinea pigs and hamsters, Yale J. Bio Med. 47 (1974) 166-181.

[24] J.G. Bartlett, Clostridium difficile infection: historic review, Anaerobe 15 (2009) 227-229.

[25] J. Finney, Gastro-enterostomy for cicatrizing ulcer of the pylonus, Johs Hopkins Hosp. Bull. 4 (1893) 53-55.

[26] N.M. Thielman, R.L. Guerrant, Clostridium difficile and its toxins, in: J. Mogs, B. Iglewski, M. Vaughan, T.A. Tu (Eds.), Bacterial Toxins and Virulence Factors in Disease. Handbook of Natural Toxins, Marcel Dekker Inc, New York, 1995, p. 328.

[27] M.R.B. Keighley, Antibiotic-associated pseudomembranous colitis: pathogenesis and management, Drugs 20 (1980) 49-56.

[28] L. Reiner, M.J. Schlesinger, G.M. Miller, Pseudomembranous colitis following aureomycin and chloramphenicol, AMA Arch. Pathol. 54 (1952) 39-67.

[29] E. Benner, W. Tellman, Pseudomembranous colitis as a sequel to oral lincomycin, Am. J. Gastroenterol. 54 (1970) 55-58.

[30] A. Scott, G. Nicholson, A. Kerr, Lincomycin as a cause of pseudomembranous colitis, Lancet 2 (1973) 1232-1234.

[31] D.N. Gerding, Clostridium difficile 30 years on: what has, or has not, changed and why? Int. J. Antimicrob. Agents 33 (2009) S2-S8.

[32] H.E. Larson, A.B. Price, Pseudomembranous colitis: presence of clostridial toxin, Lancet 2 (1977) 1312-1314.

[33] J.G. Bartlett, A.B. Onderdonk, R.L. Cisneros, D.L. Kasper, Clindamycin-associated colitis due to a toxin-producing species of Clostridium in hamsters, J. Infect. Dis. 136 (1977) 701-705.

[34] J.G. Bartlett, T. Wen Chang, M. Gurwith, S.L. Gorbach, A.B. Onderdonk, Antibiotic-associated pseudomembranous colitis due to toxin-producing clostridia, N. Engl. J. Med. 298 (1978) 531-534.

[35] G.D. Rifkin, J. Silva, R. Fekety, Gastrointestinal and systemic toxicity of fecal extracts from hamsters with clindamycin-induced colitis, Gastroenterology 74 (1978) 52-57.

[36] G.D. Rifkin, F.R. Fekety, J. Silva, Antibiotic-induced colitis implication of a toxin neutralised by Clostridium sordellii antitoxin, Lancet 2 (1977) 1103-1106.

[37] R.H. George, J.M. Symonds, F. Dimock, J.D. Brown, Y. Arabi, N. Shinagawa, et al., Identification of Clostridium difficile as a cause of pseudomembranous colitis, Br. Med. J. 1 (1978) 695.

[38] W.L. George, V.L. Sutter, E.J. Goldstein, S.L. Ludwig, S.M. Finegold, Aetiology of antimicrobial-agent-associated colitis, Lancet 1 (1978) 802-803.

[39] H.E. Larson, A.B. Price, P. Honour, S.P. Borriello, Clostridium difficile and the aetiology of pseudomembranous colitis, Lancet 1 (1978) 1063-1066.

[40] M.R. Keighley, D.W. Burdon, Y. Arabi, J.A. Williams, H. Thompson, D. Youngs, et al., Randomised controlled trial of vancomycin for pseudomembranous colitis and postoperative diarrhoea, Br. Med. J. 16 (1978) 1667-1669.

[41] T.V. Riley, Clostridium difficile: a pathogen of the nineties, Eur. J. Clin. Microbiol. Infect. Dis. 17 (1998) 137-141.

[42] F. Barbut, G. Jones, C. Eckert, Epidemiology and control of C. difficile infections in healtcare settings: an update, Curr. Opin. Infect. Dis. 24 (2011) 370-376.

[43] M.P. Hensgens, E.C. Keessen, M.M. Squire, T.V. Riley, M.G. Koene, E. de Boer, et al., Clostridium difficile infection in the community, a zoonotic disease? Clin. Microbiol. Infect. 18 (2012) 635-645.

[44] N. Yutin, M.Y. Galperin, A genomic update on clostridial phylogeny: gramnegative spore formers and other misplaced clostridia, Environ. Microbiol. 15 (2013) 2631-2641.

[45] N.L. Crogan, B.C. Evans, Clostridium difficile: an emerging epidemic in nursing homes, Geriatr. Nurs. 28 (2007) 161-164.

[46] J.M. Keller, C.M. Surawicz, Clostridium difficile infection in the elderly, Clin. Geriatr. Med. 30 (2014) 79-93.

[47] N. Nanwa, T. Kendzerska, M. Krahn, J.C. Kwong, N. Daneman, W. Witteman, et al., The economic impact of Clostridium difficile infection: a systematic review, Am. J. Gastroenterol. 110 (2015) 511-519.

[48] A.M. Jones, E.J. Kuijper, M.H. Wilcox, Clostridium difficile: a European perspective, J. Infect. 66 (2013) 115-128.

[49] P. Tattevin, S. Buffet-Bataillon, P.Y. Donnio, M. Revest, C. Michelet, Clostridium difficile infections: do we know the real dimensions of the problem? Int. J. Antimicrob. Agents 42 (2013) S36-S40.

[50] M. Natarajan, S.T. Walk, V.B. Young, D.M. Aronoff, A clinical and epidemiological review of non-toxigenic Clostridium difficile Anaerobe 22 (2013) 1-5.

[51] M.M. Riggs, A.K. Sethi, T.F. Zabarsky, E.C. Eckstein, R.L.P. Jump, C.J. Donskey, Asymptomatic carriers are a potential source for transmission of epidemic and nonepidemic Clostridium difficile strains among long-term care facility residents, Clin. Infect. Dis. 45 (2007) 992-998.

[52] J. Ryan, C. Murphy, C. Twomey, R. Paul-Ross, M.C. Rea, J. MacSharry, et al., Asymptomatic carriage of Clostridium difficile in an Irish continuing care institution for the elderly: prevalence and characteristics, Ir. J. Med. Sci. 179 (2010) 245-250.

[53] M. Arvand, V. Moser, C. Schwehn, G. Bettge-Weller, M.P. Hensgens, 
E.J. Kuijper, High prevalence of Clostridium difficile colonization among nursing home residents in Hesse, Germany, PloS One 7 (2012) e30183.

[54] D.W. Eyre, D. Griffiths, A. Vaughan, T. Golubchik, M. Acharya, L. O'Connor, et al., Asymptomatic Clostridium difficile colonisation and onward transmission, PloS One 8 (2013) e78445.

[55] J.H. Boone, M. Goodykoontz, S.J. Rhodes, K. Price, J. Smith, K.N. Gearhart, et al., Clostridium difficile prevalence rates in a large healthcare system stratified according to patient population, age, gender, and specimen consistency, Eur. J. Clin. Microbiol. 31 (2012) 1551-1559.

[56] C. Rousseau, I. Poilane, L. De Pontual, A.C. Maherault, A. Le Monnier, A. Collignon, Clostridium difficile carriage in healthy infants in the community: a potential reservoir for pathogenic strains, Clin. Infect. Dis. 55 (2012) 1209-1215.

[57] M. Delmée, G. Verellen, V. Avesani, G. Francois, Clostridium difficile in neonates: serogrouping and epidemiology, Eur. J. Pediatr. 147 (1988) 36-40.

[58] H. Kato, N. Kato, K. Watanabe, K. Ueno, H. Ushijima, S. Hashira, et al. Application of typing by pulsed-field gel electrophoresis to the study of Clostridium difficile in a neonatal intensive care unit, J. Clin. Microbiol. 32 (1994) 2067-2070.

[59] C. Simango, S. Uladi, Detection of Clostridium difficile diarrhoea in Harare, Zimbabwe, Trans. R. Soc. Trop. Med. Hyg. 108 (2014) 354-357.

[60] T. Jaeggi, G.A.M. Kortman, D. Moretti, C. Chassard, P. Holding, A. Dostal, et al., Iron fortification adversely affects the gut microbiome, increases pathogen abundance and induces intestinal inflammation in Kenyan infants, Gut 64 (2014) 731-742.

[61] D.A. Collins, P.M. Hawkey, T.V. Riley, Epidemiology of Clostridium difficile infection in Asia, Antimicrob. Resist Infect. Control 2 (2013) 21.

[62] P. Putsathit, P. Kiratisin, P. Ngamwongsatit, T.V. Riley, Clostridium difficile infection in Thailand, Int. J. Antimicrob. Agents 45 (2015) 1-7.

[63] I.T. Balassiano, E.A. Yates, R.M.C.P. Domingues, E.O. Ferreira, Clostridium difficile: a problem of concern in developed countries and still a mystery in Latin America, J. Med. Microbiol. 61 (2012) 169-179.

[64] C. Garcia, F. Samalvides, M. Vidal, E. Gotuzzo, H.L. Dupont, Epidemiology of Clostridium difficile-associated diarrhea in a Peruvian tertiary care hospital, Am. J. Trop. Med. Hyg. 77 (2007) 802-805.

[65] N.J. Ashbolt, Microbial contamination of drinking water and disease outcomes in developing regions, Toxicology 20 (2004) 229-238.

[66] A.K. Jha, B. Uppal, S. Chadha, P. Bhalla, R. Ghosh, P. Aggarwal, et al., Clinical and microbiological profile of HIV/AIDS cases with diarrhea in North India, J. Pathog. 2012 (2012) 97

[67] K. Onwueme, Y. Fadairo, L. Idoko, J. Onuh, O. Alao, P. Agaba, et al., High prevalence of toxinogenic Clostridium difficile in Nigerian adult HIV patients, Trans. R. Soc. Trop. Med. Hyg. 105 (2011) 667-669.

[68] A. Neuberger, T. Saadi, A. Shetern, E. Schwartz, Clostridium difficile Infection in travelers-a neglected pathogen? J. Travel Med. 20 (2013) 37-43.

[69] A. Kramer, I. Schwebke, G. Kampf, How long do nosocomial pathogens persist on inanimate surfaces? A systematic review, BMC Infect. Dis. 6 (2006) 130.

[70] M. Sjörberg, M. Eriksson, J. Andersson, T. Noren, Transmission of Clostridium difficile spores in isolation room environments and through hospital beds, APMIS 30 (2014).

[71] P. Verity, M.H. Wilcox, W. Fawley, P. Parnell, Prospective evaluation of environmental contamination by Clostridium difficile in isolation side rooms, J. Hosp. Infect. 49 (2001) 204-209.

[72] G.W. Kaatz, S.D. Giftin, D.R. Schaberg, K.H. Wilson, C.A. Kauffman, S.M. Seo, et al., Acquisition of Clostridium difficile from the hospital environment, Am. J. Epidemiol. 127 (1988) 1289-1294.

[73] K.H. Kim, R. Fekety, D.H. Batts, D. Brown, M. Cudmore, J. Silva Jr., et al, Isolation of Clostridium difficile from the environment and contacts of patients with antibiotic associated colitis, J. Infect. Dis. 143 (1981) 42-50.

[74] M.E. Mulligan, W.L. George, R.D. Rolfe, S.M. Finegold, Epidemiological aspects of Clostridium difficile-induced diarrhea and colitis, Am. J. Clin. Nutr. 33 (11 Suppl) (1980) 2533-2538.

[75] M.H. Wilcox, W.N. Fawley, P. Wigglesworth, P. Parnell, P. Verity, J. Freeman, Comparison of the effect of detergent versus hypochlorite cleaning on environmental contamination and incidence of $C$. difficile infection, J. Hosp. Infect. 54 (2003) 109-114.

[76] W.N. Fawley, M.H. Wilcox, Molecular epidemiology of endemic Clostridium difficile infection, Epidemiol. Infect. 126 (2001) 343-350.

[77] B.A. Walters, R. Stafford, R.K. Roberts, E. Seneviratne, Contamination and crossinfection with Clostridium difficile in an intensive care unit, Aust. N. Z. J. Med. 12 (1982) 255-258.

[78] S.E. Brooks, R.O. Veal, M. Kramer, L. Dore, N. Schupf, M. Adachi, Reduction in the incidence of Clostridium-difficile associated diarrhea in an acute care hospital and a skilled nursing facility following replacement of electronic thermometers with single use disposables, Infect. Control Hosp. Epidemiol. 13 (1992) 98-103.

[79] J.A. Jemigan, Slegman-Igra, R.C. Guerrant, B.M. Farr, Arandomized crossover study of disposable thermometers for prevention of Clostridium difficile and other nosocomial infections, Infect. Control Hosp. Epiemiol 19 (1998), 794-499.

[80] S. Brooks, A. Khan, D. Stoica, J. Griffith, L. Friedeman, R. Mukherji, et al., Reduction in vancomycin-resistant Enterococcus and Clostridium difficile infection following change to tympanic thermometers, Infect. Control Hosp. Epidemiol. 19 (1998), 336-336.
[81] C. Rodriguez, N. Korsak, B. Taminiau, V. Avesani, J. Van Broeck, P. Brach, et al., Clostridium difficile from food and surface samples in a Belgian nursing home; an unlike source of contamination, Anaerobe 32 (2015) 87-89.

[82] L.M. Kiedrowski, A. Perisetti, M.H. Loock, M.L. Khaitsa, D.M. Guerrero, Disinfection of iPad to reduce contamination with Clostridium difficile and methicillin-resistant Staphylococcus aureus, Am. J. Infect. Control 41 (2013) 1136-1137.

[83] M.A. Alqumber, Clostridium difficile in retail baskets, trolleys, conveyor belts and plastic bags in Saudi Arabia, Saudi Med. J. 35 (2014) 1274-1277.

[84] V. Pasquale, V.J. Romano, M. Rupnik, S. Dumonlet, I. Ciznar, F. Aliberti, et al., Isolation and characterization of Clostridium difficile from shellfish and marine environments, Folia Microbiol. 56 (2011) 431-437.

[85] M. del Mar Gamboa, E. Rodriguez, P. Vargas, Diversity of mesophilic clostridia in Costa Rica soils, Anaerobe 11 (2005) 322-326.

[86] V. Zidaric, S. Beigot, S. Lapajne, M. Rupnik, The occurrence and high diversity of Clostridium difficile genotypes in rivers, Anaerobe 16 (2010) 371-375.

[87] C. Simango, Prevalence of Clostridium difficile in the environment in a rura community in Zimbabwe, Trans. R. Soc. Trop. Med. Hyg. 100 (2006) 1146-1150.

[88] V. Baverud, A. Gustafsson, A. Franklin, A. Aspan, A. Gunnarsson, Clostridium difficile: prevalence in horses and environment, and antimicrobial susceptibility, Equine Vet. J. 35 (2003) 465-471.

[89] A.M. Bojesen, K.E.P. Olsen, M.F. Bertelsen, Fatal enterocolitis in Asian elephants (Elephas maximus) caused by Clostridium difficile, Vet. Microbiol. 116 (2006) 329-335.

[90] R.O.S. Silva, M.L. D’Elia, D.F. de Magalhanes Soares, A.R. Cavalcanti, R.C. Leal, C. Cavalcanti, et al., Clostridium difficile-associated diarrhea in an ocelot (Leopardus pardalis), Anaerobe 20 (2013) 82-84.

[91] E. French, A. Rodriguez-Palacios, J.T. LeJeune, Enteric bacterial pathogens with zoonotic potential isolated from farm-raised deer, Foodborne Pathog. Dis. 7 (2010) 1031-1037.

[92] R.O. Silva, M.L. D’Elia, E.P. Tostes Teixeira, P.L. Pereira, D.F. de Magalhanes Soares, A.R. Cavalcanti, et al., Clostridium difficile and Clostridium perfringens from wild carnivores species in Brazil, Anaerobe 28 (2014) 207-211.

[93] P. Bandelj, T. Trilar, R. Blagus, M. Ocepek, J. Rousseau, J.S. Weese, et al., Prevalence and molecular characterization of Clostridium difficile isolated from European Barn Swallows (Hirundo rustica) during migration, BMC Vet. Res. 10 (2014) 40.

[94] P. Bandelj, T. Trilar, J. Racnik, M. Zadrvec, T. Pirs, J. Avbersek, et al., Zero prevalence of Clostridium difficile in wild passerine birds in Europe, FEMS Microb. Lett. 321 (2011) 183-185.

[95] S. Alvarez-Perez, J.L. Blanco, E. Martinez-Nevado, T. Pelaez, C. Harmanus E. Kuijper, M.E. Garcia, Shedding of Clostridium difficile PCR-ribotype 078 by zoo animals, and report of an unstable metronidazole-resistant from a zebra foal (Equus quagga burchellii), Vet. Microbiol. 169 (2014) 218-222.

[96] C.E. Anderson, M. Haulena, E. Zabek, G. Habing, S. Raverty, Clinical and epidemiologic considerations of Clostridium difficile in harbor seals (Phoca Vitulina) at a marine mammal rehabilitation center, J. Zoo. Wildl. Med. 46 (2015) 191-197.

[97] R.O. Silva, L. Ribeiro de Almeida, C.A. Oliveira Junior, D.F. de Magalhaes Soares, P.L. Pereira, M. Rupnik, et al., Carriage of Clostridium difficile in freeliving South American coati (Nasua nasua) in Brazil, Anaerobe 30 (2014) 99-101.

[98] C.M. Jardine, R.J. Reid-Smith, J. Rousseau, J.S. Weese, Detection of Clostridium difficile in samlet and medium-sized wild mammals in Southern Ontario, Canada, J. Wildl. Dis. 49 (2013) 418-421.

[99] C.G. Himsworth, D.M. Patrick, S. Mak, C.M. Jardine, P. Tang, J.S. Weese, Carriage of Clostridium difficile by wild urban Norway rats (Rattus norvegicus) and black rats (Rattus rattus), Appl. Environ. Microbiol. 80 (2014) 1299-1305.

[100] S. Thakur, M. Sandfoss, S. Kennedy-Stoskopf, C.S. DePerno, Detection of Clostridium difficile and Salmonella in feral swine population in North Carolina, J. Wildl. Dis. 47 (2011) 774-776.

[101] S. Alvarez-Perez, J.L. Blanco, T. Pelaez, R.J. Astorga, C. Harmanus, E. Kuijper, et al., High prevalence of the epidemic Clostridium difficile PCR-ribotype 078 in Iberian free-range pigs, Res. Vet. Sci. 95 (2013) 358-361.

[102] J.S. Weese, R. Finley, R.R. Reid-Smith, N. Janecko, J. Rousseau, Evaluation of Clostridium difficile in dogs and the household environment, Epidemiol. Infect. 138 (2010) 1100-1104.

[103] M. Usui, K. Suzuki, K. Oka, K. Miyamoto, M. Takahashi, T. Inamatsu, et al. Distribution and characterization of Clostridium difficile isolated from dogs in Japan, Anaerobe 37 (2016) 58-61.

[104] I. Hussain, R.K. Sharma, P. Borah, S. Rajkhowa, I. Hussain, L.M. Barkalita, et al. Isolation and characterization of Clostridium difficile from pet dogs in Assam, India, Anaerobe 36 (2015) 9-13.

[105] S. Alavarez-Pérez, J.L. Blanco, T. Pelaez, M.P. Lanzarot, C. Harmanus, E. Kuijper, et al., Faecal shedding of antimicrobial-resistant Clostridium difficile strains by dogs, J. Small Anim. Pract. 56 (2015) 190-195.

[106] K.J. Wetterwik, G. Trowald-Wigh, L.L. Fernstrom, K. Krovacek, Clostridium difficile in faeces from healthy dogs and dogs with diarrhea, Acta Vet. Scand. 55 (2013) 23.

[107] J.S. Weese, J. Amstrong, Outbreak of Clostridium difficile-associated disease in a small animal veterinary teaching hospital, J. Ver. Intern Med. 17 (2003) $813-816$.

[108] A. Schneeberg, M. Rupnik, H. Neubauer, C. Seyboldt, Prevalence and 
distribution of Clostridium difficile PCR-ribotypes in cats and dogs from animal shelters in Thuringia, Germany, Anaerobe 18 (2012) 484-488.

[109] J.S. Weese, H.E. Weese, T.L. Bourdeau, H.R. Staempfli, Suspected Clostridium difficile-associated diarrhea in two cats, J. Am. Med. Assoc. 121 (2001) 1436-1439.

[110] B.R. Madewell, J.K. Bea, S.A. Kraegel, M. Winthrop, Y.J. Tang, J. Silva Jr., Clostridium difficile: a survey of fecal carriage in cats in a veterinary medical teaching hospital, J. Vet. Diagn Invest 11 (1999) 50-54.

[111] S.S. Diab, G. Songer, F.A. Uzal, Clostridium difficile infection in horses: a review, Vet. Microbiol. 167 (2013) 42-49.

[112] C. Rodriguez, B. Taminiau, B. Brévers, V. Avesani, J. Van Broeck, A. Leroux, et al., Faecal microbiota characterisation of horses using 16 rda barcoded pyrosequencing, and carriage rate of Clostridium difficile at hospital, BMC Microbiol. 15 (2015) 181.

[113] C. Rodriguez, B. Taminiau, B. Brévers, V. Avesani, J. Van Broeck, A.A. Leroux, et al., Carriage and acquisition rates of Clostridium difficile in hospitalized horses, including molecular characterization, multilocus sequence typing and antimicrobial susceptibility of the bacterial isolates, Vet. Microbiol. 172 (2014) 309-317.

[114] C.E. Medina-Torres, J.S. Weese, H.R. Staempfli, Prevalence of Clostridium difficile in horses, Vet. Microbiol. 152 (2011) 212-215.

[115] S. Thean, B. Elliott, T.V. Riley, Clostridium difficile in horses in Australia-a preliminary study, J. Med. Microbiol. 60 (2011) 1188-1192.

[116] C. Rodriguez, V. Avesani, J. Van Broeck, B. Taminiau, M. Delmée, G. Daube, Presence of Clostridium difficile in pigs and cattle intestinal contents and carcass contamination slaughterhouse in Belgium, Int. J. Food Microbiol. 166 (2013) 256-262.

[117] T. Norén, K. Johansson, M. Unemo, Clostridium difficile PCR-ribotype 046 is common among neonatal pigs and humans in Sweden, Clin. Microbiol. Infect. 20 (2014) 02-06.

[118] A. Indra, H. Lassnig, N. Baliko, P. Much, A. Fiedler, S. Huhulescu, et al., Clostridium difficile: a new zoonotic agent? Wien Kin. Wochensr 121 (2009) 91-95.

[119] E.C. Keessen, A.J. van den Berkt, N.H. Haasjes, C. Hermanus, E.J. Kuijper, L.J. Lipman, The relation between farm specific factors and prevalence of Clostridium difficile in slaughter pigs, Vet. Microbiol. 154 (2011) 130-134.

[120] E. Hoffer, H. Haechler, R. Frei, R. Stephan, Low occurrence of Clostridium difficile in faecal samples of healthy calves and pigs at slaughter and in minced meat in Switzerland, J. Food Prot. 73 (2010) 973-975.

[121] A.A. Bakker, E. Davis, T. Rehberger, D. Rosener, Prevalence and diversity of toxigenic Clostridium perfringens and Clostridium difficile among swine herds in the Midwest, Appl. Environ. Microbiol. 76 (2010) 2961-2967.

[122] J.S. Weese, J. Rousseau, A. Deckert, S. Gow, Reid-Smith RJ.Clostridium difficile and methicillin-resistant Staphylococcus aureus shedding by slaughter-age pigs, BMC Vet. Res. 7 (2011) 41

[123] M.M. Squire, G.P. Carter, K.E. Mackin, A. Chakravorty, T. Noren, B. Elliot, et al., Novel molecular type of Clostridium difficile in neonatal pigs, Western Australia, Emerg. Infect. Dis. 19 (2013) 790-792.

[124] T. Asai, M. Usui, M. Hiki, M. Kawanishi, H. Nagai, Y. Sasaki, Clostridium difficile isolated from the faecal contents of swine in Japan, J. Vet. Med. Sci. 75 (2013) 539-541.

[125] J. Avbersek, S. Janezic, M. Pate, M. Rupnik, V. Zidaric, et al., Diversity of Clostridium difficile in pigs and other animals in Slovenia, Anaerobe 15 (2009) $252-255$.

[126] A. Schneeberg, H. Neubauer, G. Schmoock, E. Grossmann, C. Seyboldt, Presence of Clostridium difficile PCR-ribotype clusters related to 033, 078 and 045 in diarrhoeic calves in Germany, J. Med. Microbiol. 62 (2013) 1190-1198.

[127] A. Doosti, A. Mokhtari-Farsani, Study of the frequence of Clostridium difficile tcdA, tcdB, cdtA and cdtB genes in feces of calves in soyjt west of Iran, Ann. Clin. Microbiol. 13 (2014) 21.

[128] A. Rodriguez-Palacios, T. Barman, J.T. LeJeune, Three-week summer period prevalence of Clostridium difficile in farm animals in a temperate region of the United States (Ohio), Can. Vet. J. 55 (2014) 786-789.

[129] A. Rodriguez-Palacios, S. Borgmann, T. LeJeune, Clostridium difficile in foods and animals: history and measures to reduce exposure, Anim. Health Res. Rev. 14 (2013) 11-29.

[130] D.R. Bonne, R.W. Castenholz, Bergey's Manual of Systematic Bacteriology, 2th ed., Springer-Verlag, New York, 2001.

[131] L.J. Wheeldon, T. Worthington, P.A. Lambert, Histidine acts as a co-germinant with glycine and taurocholate for Clostridium difficile spores, J. Appl. Microbiol. 110 (2011) 987-994.

[132] P.G. Engelkirk, J.L. Duben-Engelkirk, Laboratory Diagnosis of Infectious Diseases: Essentials of Diagnostic Microbiology, first ed., Wolters Kluwer Health/Lippincott Williams \& Wilkins, Baltimore, 2008.

[133] W.L. George, V.L. Sutter, D. Citron, S.M. Finegold, Selective and differential medium for isolation of Clostridium difficile, J. Clin. Microbiol. 9 (1979) 214-219.

[134] L.F. Dawson, R.A. Stabler, B.W. Wren, Assessing the role of p-cresol tolerance in Clostridium difficile, J. Med. Microbiol. 57 (2008) 745-749.

[135] D. Drudy, S. Fanning, L. Kyne, Toxin A-negative, toxin B-positive Clostridium difficile, Int. J. Infect. Dis. 11 (2007) 5-10.

[136] D. Lyras, J.R. O'Connor, P.M. Howarth, S.P. Sambol, G.P. Carter, T. Phumoonna, et al., Toxin B is essential for virulence of Clostridium difficile, Nature 458 (2009) 1176-1179.

[137] S.A. Kuehne, S.T. Cartman, N.P. Minton, Both, toxin A and toxin B, are important in Clostridium difficile infection, Gut microbes 2 (2011) 252-255.

[138] R.J. Van den Berg, E.C.J. Claas, D.H. Oyib, C.H.W. Klaassen, L. Dijkshoorn, Brazier, et al., Characterization of toxin A-negative, toxin B-positive Clostridium difficile isolates from outbreaks in different countries by amplified fragment length polymorphism and PCR ribotyping, J. Clin. Microbiol. 42 (2004) 1035-1041.

[139] M.M. Squire, G.P. Carter, K.E. Mackin, A. Chakravorty, T. Norén, B. Elliott, D. Lyras, et al., Novel molecular type of Clostridium difficile in neonatal pigs, Western Australia, Emerg. Infect. Dis. 19 (2013) 790-792.

[140] L. Lemée, A. Dhalluin, S. Testelin, M.A. Mattrat, K. Maillard, J.F. Lemeland, et al., Multiplex PCR targeting tpi (triose phosphate isomerase), tcdA (Toxin A), and tcdB (Toxin B) genes for toxigenic culture of Clostridium difficile, J. Clin. Microbiol. 42 (2004) 5710-5714.

[141] D.E. Voth, J.D. Ballard, Clostridium difficile toxins: mechanism of action and role in disease, Clin. Microbiol. Rev. 18 (2005) 247-263.

[142] J.L. Trudel, Clostridium difficile colitis, Clin. Colon Rectal Surg. 20 (2007) $13-17$.

[143] S. Stubbs, M. Rupnik, M. Gibert, J. Brazier, B. Duerden, M. Popoff, Production of actin-specific ADP-ribosyltransferase (binary toxin) by strains of Clostridium difficile, FEMS Microbiol. Lett. 186 (2000) 307-312.

[144] S. Hemmasi, B.A. Czulkies, B. Schorch, A. Veit, K. Aktories, P. Papatheodorou, Interaction of the Clostridium difficile binary toxin CDT and its host cell receptor, lipolysis-stimulated lipoprotein receptor (LSR), J. Biol. Chem. 290 (2015) 14031-14044.

[145] C. Schwan, B. Stecher, T. Tzivelekidis, M. van Ham, M. Rohde, W.D. Hardt, et al., Clostridium difficile toxin CDT induces formation of microtubule-based protrusions and increases adherence of bacteria, PLoS Pathog. 5 (2009) e1000626.

[146] S. Bacci, K. Mølbak, M.K. Kjeldsen, K.E.P. Olsen, Binary toxin and death after Clostridium difficile infection, Emerg. Infect Dis. 17 (2011) 976-982.

[147] Y. Tagashira, H. Kato, M. Senoh, A. Nakamura, Two cases of fulminant colitis due to binary toxin-positive Clostridium difficile that are not PCR ribotype 027 or type 078, J. Med. Microbiol. 62 (2013) 1486-1489.

[148] D.B. Stewart, A. Berg, J. Hegarty, Predicting recurrence of C. difficile colitis using bacterial virulence factors: binary toxin is the key, J. Gastrointest. Surg. 17 (2013) 118-124.

[149] C. Eckert, A. Emirian, A. Le Monnier, L. Cathala, H. De Montclos, J. Goret, et al. Prevalence and pathogenicity of binary toxin-positive Clostridium difficile strains that do not produce toxins A and B, New Microbes New Infect. 3 (2015) 12-17.

[150] M. Delmée, Laboratory diagnosis of Clostridium difficile disease, Clin. Microbiol. Infect. 7 (2001) 411-416.

[151] E.J. Baron, J.M. Miller, M.P. Weinstein, S.S. Richter, P.H. Gilligan, B. Richard, et al., A guide to utilization of the microbiology laboratory for diagnosis of infectious diseases: 213 recommendations by the Infectious Disease Society of America (IDSA) and the America Society for Microbiology (ASM), Clin. Microbiol. Infect. Dis. 57 (2013) e22-e121.

[152] K.H. Wilson, Efficiency of various bile salt preparations for stimulation of Clostridium difficile spore germination, J. Clin. Microbiol. 18 (1983) 1017-1019.

[153] K.L. Tyrrell, D.M. Citron, E.S. Leoncio, C.V. Merriam, E.J.C. Goldstein, Evaluation of cycloserine-cefoxitin fructose agar (CCFA), CCFA with horse blood and taurocholate, and cycloserine-cefoxitin mannitol broth with taurocholate and lysozyme for recovery of Clostridium difficile isolates from fecal samples, J. Clin. Microbiol. 51 (2013) 3094-3096.

[154] M. Delmée, G. Wauters, The role of Clostridium difficile in diarrhea appearing after antibiotic treatment: a study of 87 cases, Acta Clin. Belg 36 (1981) 178-184

[155] DR1107, C. difficile Test Kit | Oxoid - Product Detail n.d. http://www.oxoid. com/UK/blue/prod_detail/prod_detail.asp?pr=DR1107\&minfo=Y (accessed 10.12.15).

[156] S.B. Han, J. Chang, S.H. Shin, K.G. Park, G.D. Lee, Y.G. Park, et al., Performance of chromID Clostridium difficile agar compared with BBL C. difficile selective agar for detection of C. difficile in stool specimens, Ann. Lab. Med. 34 (2014) $376-379$.

[157] J.J. Yang, Y.S. Nam, M.J. Kim, S.Y. Cho, E. You, Y.S. Soh, et al., Evaluation of a chromogenic culture medium for the detection of Clostridium difficile, Yonsei Med. J. 55 (2014) 994-998.

[158] B.-M. Shin, E.J. Lee, Comparison of ChromID agar and Clostridium difficile selective agar for effective isolation of $C$. difficile from stool specimens, Ann. Lab. Med. 34 (2014) 15-19.

[159] K.C. Carson, L.V. Boseiwaqa, S.K. Thean, N.F. Foster, T.V. Riley, Isolation of Clostridium difficile from faecal specimens - a comparison of chromID C. difficile agar and cycloserine-cefoxitin-fructose agar, J. Med. Microbiol. 62 (2013) 1423-1427.

[160] M. Lister, E. Stevenson, D. Heeg, N.P. Minton, S.A. Kuehne, Comparison of culture based methods for the isolation of Clostridium difficile from stool samples in a research setting, Anaerobe 28 (2014) 226-229.

[161] B. Limbago, A.D. Thompson, S.A. Greene, D. MacCannell, C.E. MacGowan, B. Jolbitado, et al., Development of a consensus method for culture of Clostridium difficile from meat and its use in a survey of U.S. retail meats, Food Microbiol. 32 (2012) 448-451.

[162] J.L. Blanco, S. Álvarez-Pérez, M.E. García, Is the prevalence of Clostridium difficile in animals underestimated? Vet. J. 197 (2013) 694-698.

[163] S.P. Borriello, P. Honour, Simplified procedure for the routine isolation of 
Clostridium difficile from faeces, J. Clin. Pathol. 34 (1981) 1124-1127.

[164] J.S. Weese, B.P. Avery, J. Rousseau, R.J. Reid-Smith, Detection and enumeration of Clostridium difficile spores in retail beef and pork, Appl. Environ. Microbiol. 75 (2009) 5009-5011.

[165] J.G. Bartlett, D.N. Gerding, Clinical recognition and diagnosis of Clostridium difficile infection, Clin. Infect. Dis, 46 (Suppl 1) (2008). S12-S8.

[166] L.R. Peterson, R.U. Manson, S.M. Paule, D.M. Hacek, A. Robicsek, R.B. Thomson, et al., Detection of toxigenic Clostridium difficile in stool samples by real-time polymerase chain reaction for the diagnosis of $C$. difficile-associated diarrhea, Clin. Infect. Dis. 45 (2007) 1152-1160.

[167] J. Avbersek, M. Cotman, M. Ocepek, Detection of Clostridium difficile in animals: comparison of real-time PCR assays with the culture method, J. Med Microbiol 60 (2011) 1119-1125.

[168] B.A. Houser, A.L. Hattel, B.M. Jayarao, Real-time multiplex polymerase chain reaction assay for rapid detection of Clostridium difficile toxin-encoding strains, Foodborne Pathog. Dis. 7 (2010) 719-726.

[169] R. Mutters, C. Nonnenmacher, C. Susin, U. Albrecht, R. Kropatsch, S. Schumacher, Quantitative detection of Clostridium difficile in hospital environmental samples by real-time polymerase chain reaction, J. Hospl Infect. 71 (2009) 43-48.

[170] F. Barbut, M. Braun, B. Burghoffer, V. Lalande, C. Eckert, Rapid detection of toxigenic strains of Clostridium difficile in diarrheal stools by real-time PCR, J. Clin. Microbiol. 47 (2009) 1276-1277.

[171] G. Terhes, E. Urbán, J. Sóki, E. Nacsa, E. Nagy, Comparison of a rapid molecular method, the BD GeneOhm Cdiff assay, to the most frequently used laboratory tests for detection of toxin-producing Clostridium difficile in diarrheal feces, J. Clin. Microbiol. 47 (2009) 3478-3481.

[172] S.D. Goldenberg, T. Dieringer, G.L. French, Detection of toxigenic Clostridium difficile in diarrheal stools by rapid real-time polymerase chain reaction, Diagn Microbiol. Infect. Dis. 67 (2010) 304-307.

[173] M. Sartelli, A. Malangoni, F.M. Abu-Zidan, E.W. Griffiths, S. Di Bella, L. McFarland, et al., WSES guidelines for management of Clostridium difficile infection in surgical patients, World J. Emerg. Surg. 10 (2015) 38.

[174] J. Antikainen, T. Pasanen, S. Mero, E. Tarkka, J. Kirveskari, S. Kotila, et al. Detection of virulence genes of Clostridium difficile by multiplex PCR, APMIS 117 (2009) 607-613.

[175] C.A. Huber, N.F. Foster, T.V. Riley, D.L. Paterson, Challenges for standardization of Clostridium difficile typing methods, J. Clin. Microbiol. 51 (2013) 2810-2814.

[176] G.H. Mazurek, V. Reddy, B.J. Marston, W.H. Haas, J.T. Crawford, DNA fingerprinting by infrequent-restriction-site amplification, J. Clin. Microbiol. 34 (1996) 2386-2390.

[177] M.M. Read, Trends in DNA Fingerprinting Research, first ed., Nova Science Publisher Inc, New York, 2005.

[178] I. Filippis, M.L. McKee, Molecular Typing in Bacterial Infections, Springer Science \& Business Media, New York, 2012.

[179] S.L. Stubbs, J.S. Brazier, G.L. O'Neill, B.I. Duerden, PCR targeted to the 16S-23S rRNA gene intergenic spacer region of Clostridium difficile and construction of a library consisting of 116 different PCR ribotypes, J. Clin. Microbiol. 37 (1999) 461-463.

[180] P. Bidet, F. Barbut, V. Lalalnde, B. Burghoffer, J.C. Petit, Development of a new PCR-ribotyping for Clostridium difficile based on ribosomal RNA gene sequencing, FEMS Microbiol. Lett. 175 (1999) 261-266.

[181] D.R. Knight, B. Elliott, B.J. Chang, T.T. Perkins, T.V. Riley, Diversity and evolution in the genome of Clostridium difficile, Clin. Microbiol. Rev. 28 (2015) $721-741$.

[182] A. Indra, S. Huhulescu, M. Schneeweis, P. Hasenberger, S. Kernbichler, A. Fiedler, et al., Characterization of Clostridium difficile isolates using capillary gel electrophoresis-based PCR ribotyping, J. Med. Microbiol. 57 (2008) 1377-1382.

[183] S. Janezic, I. Strumbelj, M. Rupnik, Use of modified PCR ribotyping for direct detection of Clostridium difficile ribotypes in stool samples, J. Clin. Microbiol. 49 (2011) 3024-3025.

[184] S. Janezic, I. Strumbelj, M. Rupnik, Use of modified PCR ribotyping for direct detection of Clostridium difficile ribotypes in stool samples, J. Clin. Microbiol. 49 (2011) 3024-3025.

[185] M. Xiao, F. Kong, P. Jin, Q. Wang, K. Xiao, N. Jeoffreys, et al., Comparison of two capillary gel electrophoresis systems for Clostridium difficile ribotyping using a panel of ribotype 027 isolates and whole-genome sequences as a reference standard, J. Clin. Microbiol. 50 (2012) 2755-2760.

[186] M. Delmée, C. Depitre, G. Corthier, A. Ahoyo, V. Avesani, Use of an enzymelinked immunoassay for Clostridium difficile serogrouping, J. Clin. Microbiol. 31 (1993) 2526-2528.

[187] H. Kato, H. Kato, Y. Ito, T. Akahane, S. Izumida, T. Yokoyama, et al., Typing of Clostridium difficile isolates endemic in Japan by sequencing of $\operatorname{sipA}$ and its application to direct typing, J. Med. Microbiol. 59 (2010) 556-562.

[188] I. Joost, K. Speck, M. Herrmann, L. von Müller, Characterisation of Clostridium difficile isolates by slpA and tcdC gene sequencing, Int. J. Antimicrob. Agents
33 (Suppl 1) (2009) S13-s18.

[189] K.E. Dingle, X. Didelot, M.A. Ansari, D.W. Eyre, A. Vaughan, D. Griffiths, et al, Recombinational switching of the Clostridium difficile S-layer and a novel glycosylation gene cluster revealed by large-scale whole-genome sequencing, J. Infect. Dis. 207 (2013) 675-686.

[190] G. Northey, M. Gal, A. Rahmati, J.S. Brazier, Subtyping of Clostridium difficile PCR ribotype 001 by REP-PCR and PFGE, J. Med. Microbiol. 54 (2005) $543-547$.

[191] K.L. Hiett, B.S. Seal, Use of repetitive element palindromic PCR (rep-PCR) for the epidemiologic discrimination of foodborne pathogens, Methods Mol. Biol. 551 (2009) 49-58.

[192] C. Eckert, J. Van Broeck, P. Spigaglia, B. Burghoffer, M. Delmée, Mastrantonio et al., Comparison of a commercially available repetitive-element PCR system (DiversiLab) with PCR ribotyping for typing of Clostridium difficile strains, J. Clin. Microbiol. 49 (2011) 3352-3354.

[193] L.M. Green, T. Worthington, A.C. Hilton, P.A. Lambert, Genetic characterization of clinical isolates of Clostridium difficile using an optimized RAPD protocol and PCR ribotyping reveals strain diversity between two tertiary referral Trusts in the West Midlands, UK, J. Med. Microbiol. 60 (2001) $1287-1291$.

[194] F. Barbut, N. Mario, M. Delmée, J. Gozian, Genomic fingerprinting of Clostridium difficile isolates by using a random amplified polymorphic DNA (RAPD) assay, FEMS Microbiol. Lett. 114 (1993) 161-166.

[195] N.K. Fry, P.H.M. Savelkoul, P. Visca, Amplified fragment-length polymorphism analysis, Methods Mol. Biol. 551 (2009) 89-104.

[196] C.H.W. Klaassen, H.A. van Haren, A.M. Horrevorts, Molecular fingerprinting of Clostridium difficile isolates: pulsed-field gel electrophoresis versus amplified fragment length polymorphism, J. Clin. Microbiol. 40 (2002) $101-104$.

[197] P. Spigaglia, P. Mastrantonio, Molecular analysis of the pathogenicity locus and polymorphism in the putative negative regulator of toxin production (TcdC) among Clostridium difficile clinical isolates, J. Clin. Microbiol. 40 (2002) $3470-3475$.

[198] S. Janezic, M. Marín, A. Martín, M. Rupnik, A new type of toxin A-negative, toxin B-positive Clostridium difficile strain lacking a complete tcdA gene, J. Clin. Microbiol. 53 (2015) 692-695.

[199] D. Griffiths, W. Fawley, M. Kachrimanidou, R. Bowden, D.W. Crook, R. Fung et al., Multilocus sequence typing of Clostridium difficile, J. Clin. Microbiol. 48 (2010) 770-778.

[200] L. Lemée, A. Dhalluin, M. Pestel-Caron, J.F. Lemeland, J.L. Pons, Multilocus sequence typing analysis of human and animal Clostridium difficile isolates of various toxigenic types, J. Clin. Microbiol. 42 (2004a) 2609-2617.

[201] A. Schneeberg, H. Neubauer, G. Schmoock, E. Grossmann, C. Seyboldt, Presence of Clostridium difficile PCR ribotype clusters related to 033, 078 and 045 in diarrhoeic calves in Germany, J. Med. Microbiol. 62 (2013) 1190-1198.

[202] J. Zaluga, P. Stragier, J. Van Vaerenbergh, M. Maes, P. De Vos, Multilocus variable-number-tandem-repeats analysis (MLVA) distinguishes a clonal complex of Clavibacter michiganensis subsp. michiganensis strains isolated from recent outbreaks of bacterial wilt and canker in Belgium, BMC Microbiol. 13 (2013) 126.

[203] P.C. Ng, E.F. Kirkness, Whole genome sequencing, Methods Mol. Biol. 628 (2010) 215-226.

[204] D.W. Eyre, M.L. Cule, D.J. Wilson, D. Griffiths, A. Vaughan, L. O'Connor, et al., Diverse sources of $C$. difficile infection identified on whole-genome sequencing, N. Engl. J. Med. 369 (2013) 1195-1205.

[205] G. Killgore, A. Thompson, S. Johnson, J. Brazier, E. Kuijper, J. Pepin, et al., Comparison of seven techniques for typing international epidemic strains of Clostridium difficile: restriction endonuclease analysis, pulsed-field gel electrophoresis, PCR-ribotyping, multilocus sequence typing, multilocus variable-number tandem-repeat an, J. Clin. Microbiol. 46 (2007) 431-437.

[206] C. Rodriguez, B. Taminiau, B. Brévers, V. Avesani, J. Van Broeck, A. Leroux, et al., Faecal microbiota characterisation of horses using rDNA barcoded pyrosequencing, and carriage rate of Clostridium difficile at hospital admission, BMC Microbiol. 15 (2015) 181.

[207] C. Rodriguez, B. Taminiau, J. Van Broeck, M. Delmée, G. Daube, Clostridium difficile infection and intestinal microbiota interactions, Microb. Pathog. 89 (2015) 201-209.

[208] D. Shahinas, M. Silverman, T. Sittler, C. Chiu, P. Kim, E. Allen-Vercoe, et al. Toward an understanding of changes in diversity associated with fecal microbiome transplantation based on 16S rRNA gene deep sequencing, MBio 23 (2012), 3(5).

[209] K. Daly, C.S. Stewart, H.J. Flint, S.P. Shirazi-Beechey, Bacterial diversity within the equine large intestine as revealed by molecular analysis of cloned $16 \mathrm{~S}$ rRNA genes, FEMS Microbiol. Ecol. 38 (2011) 141-151.

[210] H.B. Nielsen, M. Almeida, A.S. Juncker, S. Rasmussen, J. Li, S. Sunagawa, et al., Identification and assembly of genomes and genetic elements in complex metagenomic samples without using reference genomes, Nat. Biotech. 32 (2014) 822-828. 